
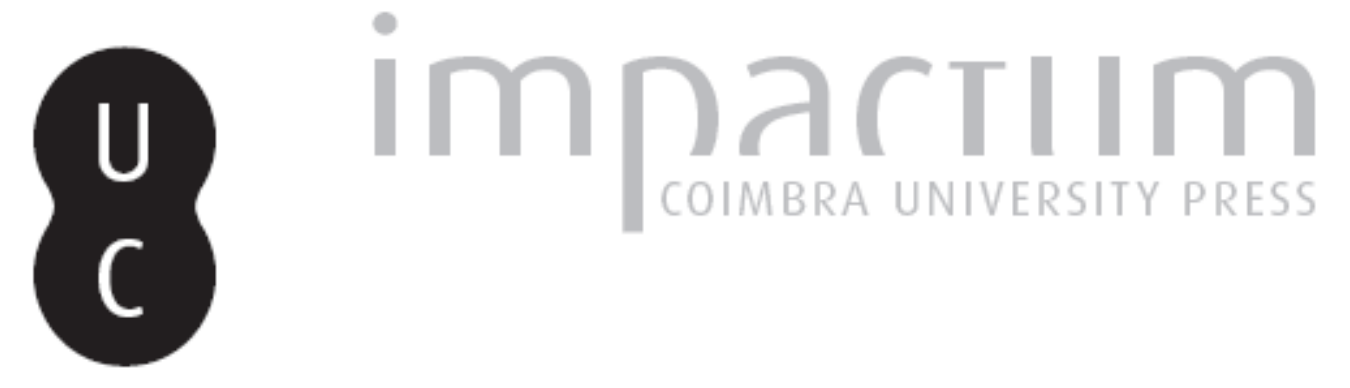

\title{
Condições meteorológicas e ocorrência de incêndios florestais em Portugal Continental (1971-2010)
}

Autor(es): $\quad$ Lourenço, Luciano; Bernardino, Sofia

Publicado por: $\begin{aligned} & \text { Faculdade de Letras da Universidade de Coimbra, Departamento de } \\ & \text { Geografia }\end{aligned}$

URL

persistente:

URI:http://hdl.handle.net/10316.2/30203

DOI: $\quad$ DOI:http://dx.doi.org/10.14195/0871-1623_32_9

Accessed : $\quad$ 26-Apr-2023 13:25:08

A navegação consulta e descarregamento dos títulos inseridos nas Bibliotecas Digitais UC Digitalis, UC Pombalina e UC Impactum, pressupõem a aceitação plena e sem reservas dos Termos e Condições de Uso destas Bibliotecas Digitais, disponíveis em https://digitalis.uc.pt/pt-pt/termos.

Conforme exposto nos referidos Termos e Condições de Uso, o descarregamento de títulos de acesso restrito requer uma licença válida de autorização devendo o utilizador aceder ao(s) documento(s) a partir de um endereço de IP da instituição detentora da supramencionada licença.

Ao utilizador é apenas permitido o descarregamento para uso pessoal, pelo que o emprego do(s) título(s) descarregado(s) para outro fim, designadamente comercial, carece de autorização do respetivo autor ou editor da obra.

Na medida em que todas as obras da UC Digitalis se encontram protegidas pelo Código do Direito de Autor e Direitos Conexos e demais legislação aplicável, toda a cópia, parcial ou total, deste documento, nos casos em que é legalmente admitida, deverá conter ou fazer-se acompanhar por este aviso.

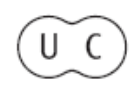




\title{
Condições meteorológicas e ocorrência de incêndios florestais em Portugal Continental (1971-2010)
}

\author{
Luciano Lourenço \\ Departamento de Geografia e Núcleo de Investigação Científica de Incêndios Florestais (NICIF). Faculdade de Letras da Universidade de Coimbra.
}

\section{Sofia Bernardino}

Núcleo de Investigação Científica de Incêndios Florestais (NICIF). Faculdade de Letras da Universidade de Coimbra.

\section{Resumo:}

Em Portugal Continental, ao longo dos últimos quarenta anos, verificou-se um aumento significativo do número de ocorrências de incêndios florestais, bem como da dimensão da área ardida, situação que acarreta um grande leque de consequências ambientais e prejuízos socioeconómicos, conduzindo paulatinamente o País para uma alteração/degradação da sua floresta.

Apesar da génese dos incêndios florestais ser, na sua grande maioria, devida a causas de natureza antrópica, pois "o desenvolvimento espontâneo do fogo, embora possível, é raro" (REBELo, 2003: 15), as condições meteorológicas são parte integrante do comportamento dos incêndios, mormente nas regiões de clima mediterrâneo, como é o caso da generalidade do território continental, sendo elas que, muitas vezes, acabam por ditar as características dos incêndios florestais.

Para o comprovar, analisou-se a relação entre a ocorrência e o desenvolvimento dos incêndios florestais em Portugal continental, num período de quarenta anos, com as condições meteorológicas existentes, expressas através dos respetivos valores de temperaturas e humidades relativas do ar, bem como da precipitação, e os resultados obtidos apontam claramente para uma elevada correlação entre determinados tipos de tempo e elevados valores de eclosão e propagação de incêndios, do mesmo modo que outros tipos de tempo se revelarem extremamente prejudiciais à manifestação e desenvolvimento de incêndios.

Palavras-chave: Floresta. Incêndios florestais. Condições meteorológicas. Tipos de tempo.

\section{Résumé:}

Conditions météorologiques et occurrence des incendies de forêt au Portugal (1971-2010)

Au Portugal, au cours des quarante dernières années, il ya avait une augmentation significative du nombre d'occurrences de feux de forêt, ainsi que la taille de la zone brûlée, une situation qui porte un large gamme d'impacts environnementaux et socio-économiques, peu à peu conduit le pays à une altération / dégradation de leurs forêts.

Bien que la genèse des incendies de forêt sont, la plupart du temps due à causes anthropiques, car «le développement spontané de l'incendie, bien que possible, est rare» (ReBelo, 2003: 15), les conditions météorologiques font partie intégrante du comportement des incendies, en particulier dans les régions de climat méditerranéen, comme c'est le cas de la plupart du territoire continental, dictant les caractéristiques des feux de forêt.

Pour preuve, nous avons analysé la relation entre l'occurrence et le développement des feux de forêt au Portugal continental, sur une période de quarante ans, avec les conditions météorologiques existents, exprimées à travers de les valeurs respectives de la température et de l'humidité relative de l'air et aussi de la précipitation, et les résultats indiquent clairement une corrélation élevée entre certains types de temps et les valeurs élevées d'occurrences et propagation d'incendies, de la même manière que les autres types de temps sont extrêmement nocifs pour la manifestation et le développement des incendies.

Mots-clés: Forêt. Feux de forêt. Conditions météorologiques. Types de temps.

\section{Abstract:}

Meteorological conditions and Occurrence of Forest Fires in Portugal (1971-2010)

In Portugal, over the last forty years, there has been a significant increase in the number of occurrences of forest fires, as well as the size of the burned area, a situation that causes many environmental and socio-economic damage, gradually leading the country to an alteration / degradation of their forest.

Although the genesis of forest fires, mostly correspond to causes of anthropogenic nature, because "the spontaneous development of the fire, although possible, is rare" (ReBELO, 2003: 15), the weather conditions are an 
integral part of behavior of fires, especially in regions of Mediterranean climate, as is the case of most generality of the mainland, and that they often end up dictating the characteristics of forest fires.

For demonstrate, we analyzed the relationship between the occurrence and development of forest fires in Portugal mainland, over a period of forty years, with the existing weather conditions, expressed through the respective values of temperature and relative humidity of the air and the precipitation, and the results clearly point to a high correlation between certain types of weather and high values of the outbreak and spread of fires, in the same way that other types of time prove to be extremely harmful to the manifestation and development of fire.

Keywords: Forest. Forest fires. Meteorological conditions. Weather types.

\section{Introdução}

Ao longo dos últimos quarenta anos tem-se verificado um significativo aumento dos incêndios florestais em Portugal Continental, tanto em número de ocorrências, como na dimensão das áreas ardidas, fenómeno que decorre de várias circunstâncias, mas a que as condições meteorológicas não são certamente alheias.

Ainda que a esmagadora maioria das causas de incêndio florestal seja de natureza antrópica, pois "o desenvolvimento espontâneo do fogo, embora possível, é raro, mas o seu desencadeamento na sequência de trovoadas pode acontecer, e o seu desencadeamento por acção humana, criminosa ou não, é frequente" (Rebelo, 2003: 15), no entanto, as condições meteorológicas podem favorecer ou dificultar a ignição, bem como a propagação, pelo que merecem ser analisadas a par dos incêndios, designadamente porque condicionam a humidade da vegetação, enquanto combustível dos incêndios florestais.

O estabelecimento das relações existentes entre condições meteorológicas e incêndios florestais em Portugal Continental e, a nível local, como estudo de caso, no município de Coimbra, foi efetuado no período compreendido entre 1971 e 2010, contrastando os anos que registaram verões mais frescos com aqueles em que os verões foram mais quentes.

Para este estudo a metodologia utilizada passou pela consulta bibliográfica, através da análise de obras impressas relacionadas com incêndios florestais em Portugal Continental e de estudos realizados no âmbito das condições meteorológicas, designadamente da autoria de Fernando Rebelo e Luciano Lourenço, pioneiros nos estudos sobre incêndios florestais em Portugal. Recorreu-se, também, a dados e relatórios disponibilizados em plataformas da internet, tanto do Instituto da Conservação da Natureza e das Florestas, como do Instituto de Meteorologia, e, ainda, a elementos fornecidos tanto pelo Instituto Geofísico da Universidade de Coimbra como pela Autoridade Nacional de Protecção Civil.

0 tratamento de toda a informação estatística foi efetuado em Excell e ArcGis 9.3.

\section{Incêndios Florestais em Portugal Continental (1971-2010)}

No período compreendido entre 1971 e 2010, segundo dados disponibilizados pela Autoridade Florestal Nacional para Portugal Continental, neste território foram registadas 575.557 ocorrências de incêndios florestais, a que correspondeu uma área ardida de 3.788.375 hectares, o que significa que, em média, arderam cerca de 94.700 hectares da Floresta por ano.

Os primeiros dados estatísticos de incêndios florestais remontam a finais dos anos sessenta do século passado, embora apenas digam respeito aos perímetros públicos. Como, entretanto, sobretudo a partir de meados dos anos setenta, os incêndios florestais passaram a assumir alguma importância, os registos estatísticos foram-se estendendo a todo território continental, considerando-se fiáveis a partir dos anos oitenta. A análise destes dados mostra evolução positiva, com um aumento exponencial do número de ocorrências até ao final do século passado, se bem que o recorde do número de ocorrências já se tenha registado no novo milénio, mais precisamente no ano de 2005.

Considerando os limiares estabelecidos no Plano Nacional de Defesa da Floresta Contra Incêndios (APIF, 2006) como "limite máximo anual", ou seja, 20.000 ocorrências e 100.000 hectares ardidos, e relacionando estes com os totais anuais de ambas as variáveis, facilmente verificamos que esses objetivos foram alcançados em 2006 e nos dois anos seguintes, essencialmente devido a condições meteorológicas pouco favoráveis à ocorrência e, também, à propagação de incêndios florestais, mas é fundamental reduzir o número de ocorrências, pois, a partir de 2008, voltaram a ser superiores ao limiar estabelecido (Figura 1), com as inevitáveis consequências em termos da dimensão das áreas ardidas.

No que respeita à evolução anual das áreas ardidas, ela tem sido bem mais irregular do que a das ocorrências, principalmente por estas estarem muito dependentes das condições meteorológicas. De facto, os anos de 1976 e 1977, 1988, 1997, 2007 e 2008, registaram áreas ardidas pouco significativas essencialmente 
porque as condições meteorológicas foram pouco favoráveis à progressão, uma vez que em alguns desses anos (1988, 2007 e 2008) o número de ocorrências até foi elevado.

Deste modo, no que diz respeito ao número anual de ocorrências, notou-se um acréscimo a partir de 1989, ano que registou o maior número de ocorrências até então registado e que só viria a ser ultrapassado anos mais tarde, em 1995, que como 1989 também registou um aumento despropositado, pelo que podem ser considerados anos de charneira entre duas situações distintas.

Com efeito, até 1989 os valores anuais das ocorrências foram reduzidos, uma vez que só depois aumentaram paulatinamente, entre 1990 e 1994. A partir de 1995, ano em que se atingiu um valor anormalmente elevado, superior a 34.000 ocorrências, os valores anuais mantiveram-se sempre superior ao de referência (20.000 ocorrências), com exceção dos anos de 2007 e 2008, o que mostra bem como o objetivo da redução das ignições ainda está longe de se alcançar.

No que concerne às áreas ardidas, verifica-se que, na década de 1970, se destacou o ano de 1975, por ter registado um valor superior a 100.000 hectares queimados, apesar do número total de ocorrências ter sido bastante reduzido. Curiosamente, também nas décadas seguintes, todos os anos terminados em 5 , registaram significativas áreas ardidas e com tendência sempre crescente: 1975, 1985, 1995 e 2005.

Os anos do final da década de setenta e início de oitenta foram marcados por um substancial acréscimo das áreas ardidas, relativamente aos anos anteriores, com exceção de 1975, que, entre outras, teve como consequência "a organização da defesa do património florestal do continente contra o flagelo dos incêndios", através da publicação de uma série de diplomas legais: Decreto-Lei n. ${ }^{\circ} 327 / 80$, de 26 de Agosto, Lei n. ${ }^{\circ} 10 / 81$, de 10 de Julho e Decreto Regulamentar $n .^{\circ} 55 / 81$, de 18 de Dezembro.

Estas medidas parecem ter dado algum resultado a curto prazo, uma vez que nos anos imediatos, de 1982, 1983 e 1984, observou-se alguma contenção, sobretudo nas áreas ardidas, uma vez que o número de ocorrências manteve a tendência de crescimento. Nesta década de 1980 destacaram-se os anos de 1985, pelo já referido acréscimo da área ardidas, e o de 1989, pelo exponencial aumento do número de ocorrências, tendo ambos ultrapassado os valores de referência definidos vários anos depois.

Os anos seguintes de 1990 e 1991 mantiveram esta tendência de aumento anual da área ardida, pelo que o final da década de 80 marcou o período a partir do qual se deu o agravamento dos incêndios, uma vez que até 2010 se contabilizam 12 anos com área ardida acima de 100.000 hectares, ao contrário de apenas dois anos, no período anterior. 0 maior destaque vai, naturalmente, para os anos de 2003 e de 2005, com 425.839 e com 339.088 hectares queimados (Instituto de Conservação da Natureza e das Florestas, 2012), respetivamente, que foram os piores anos da história dendrocaustológica portuguesa.

Em síntese, verificou-se um aumento constante das áreas ardidas ao longo das quatro décadas, tendo-

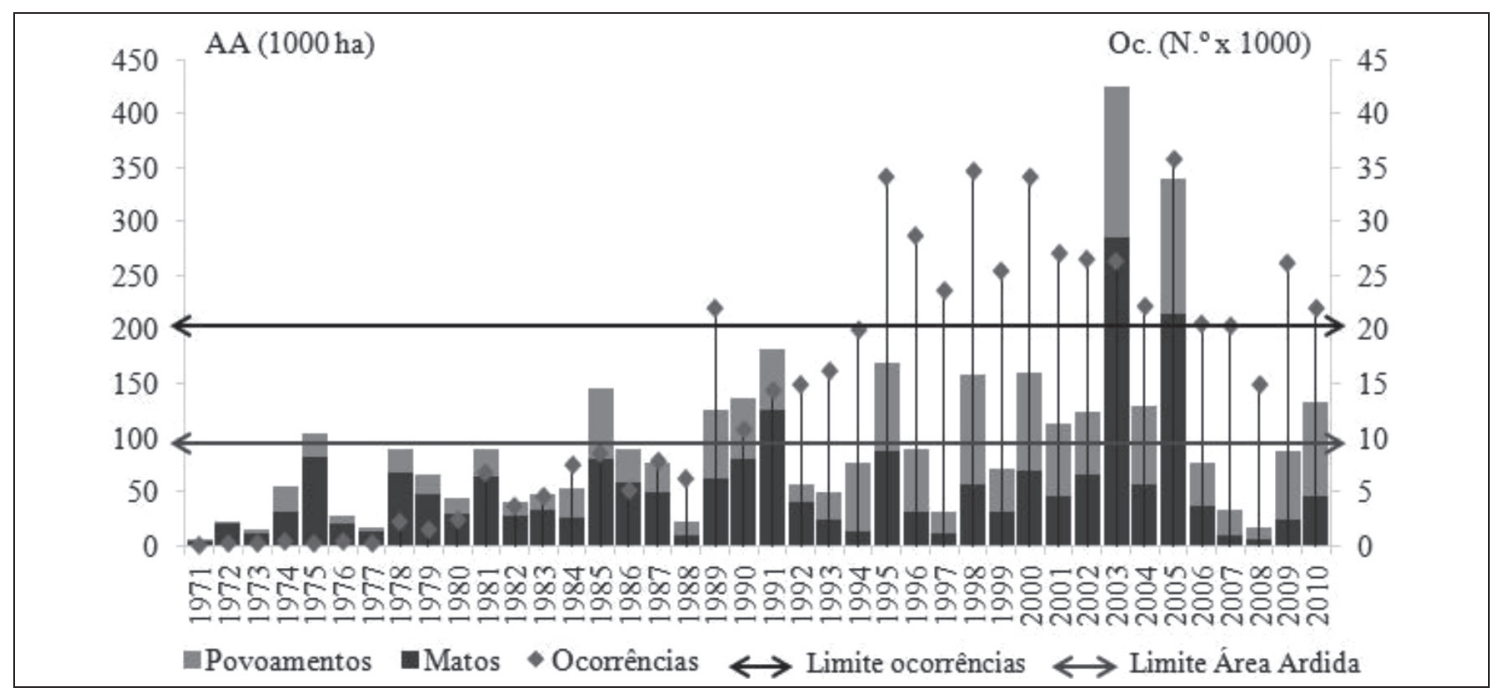

Figura 1

Evolução anual do número de ocorrências e das áreas ardidas (povoamentos e matos), em Portugal continental.

Fonte dos dados: Autoridade Florestal Nacional. 
se atingido, na década de 2000, uma dimensão 3 vezes superior àquela que se verificou na década de 1970. 0 aumento sentiu-se também ao nível das ocorrências, tendo registado um aumento mais significativo da década de 1980 para a de 1990, após o que parece tender para uma certa estabilização, contudo estes valores não deixam de ser exageradamente elevados, mais de 33 vezes superiores aos que se registaram na década de 1970 (Figura 2).

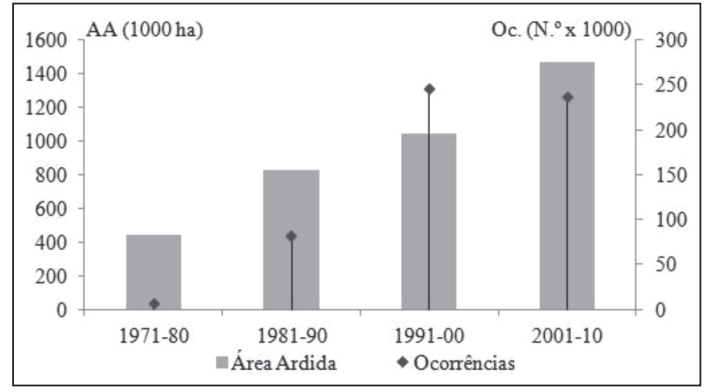

Figura 2

Evolução, por década, da área ardida em hectares e do número total de ocorrências.

Fonte dos dados: Autoridade Florestal Nacional.

Relativamente à distribuição espacial dos incêndios florestais em Portugal continental, verifica-se que no período de 1980-2010 foram os distritos do Centro e Norte interior os mais afetados em termos de área ardida, em especial os da Guarda, Castelo Branco, Viseu, Vila Real e Coimbra. Em contrapartida, foram os distritos do Sul: Évora, Setúbal, Beja e Lisboa, aqueles que apresentaram menores áreas ardidas.
Por sua vez, no respeitante ao número de ocorrências, os distritos que registaram os maiores valores situam-se no litoral Oeste e correspondem aos mais populosos: Porto, Braga, Lisboa e Aveiro. Em contraponto, foram os distritos localizados mais a sul do território continental, aqueles que registaram os valores mais baixos de ocorrências: Beja, Évora, Portalegre, Setúbal e Faro (Figuras 3 e 4)

A dura realidade que o País tem vindo a atravessar em termos de incêndios florestais, foi alvo de várias tentativas de justificação, dando cada uma delas o seu contributo para explicar as dimensões do sucedido. As profundas alterações observadas na estrutura socioeconómica da população portuguesa, em especial da residente nos espaços florestais, que se têm vindo a verificar especialmente a partir de cerca de metade do Século $X X$, têm sido enumeradas como a principal causa para tal flagelo (Cravidão, 1990; Lourenço, 1991 e Nunes, 2004).

Com efeito, a redução dos efetivos populacionais desses espaços, as mudanças na estrutura da população que neles permanece, especialmente nos setores de atividade, com grande redução do sector primário, mais ligado à agricultura e à floresta, bem como na estrutura etária, com uma população cada vez mais envelhecida, além das transformações económicas e dos hábitos da população, tais como a possibilidade de acesso a gás e eletricidade, para aquecimento e confeção de alimentos, bem como a aquisição de adubos químicos que substituíram os estrumes tradicionais, permitiram a acumulação de muita biomassa arbustiva e arbórea na floresta, que, em condições favoráveis, muito facilita a propagação dos incêndios.

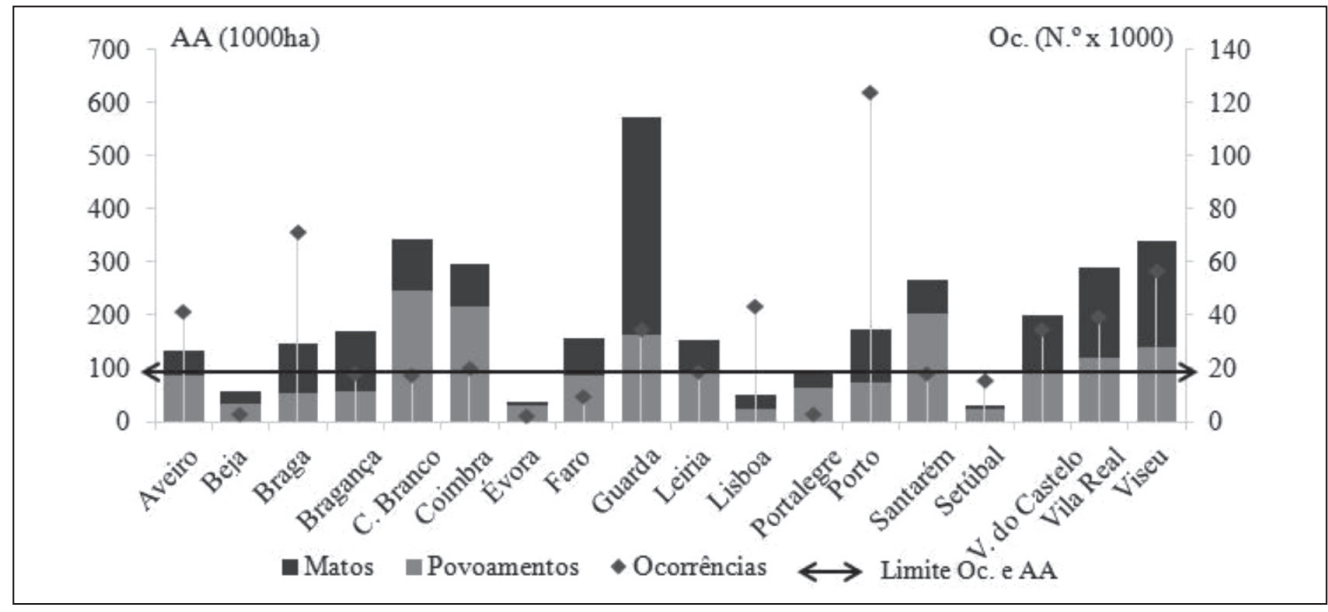

Figura 3

Distribuição do número total de ocorrências e da área ardida entre 1980-2010, por distrito. Relação com os valores de referência para o território continental.

Fonte dos dados: Autoridade Florestal Nacional. 


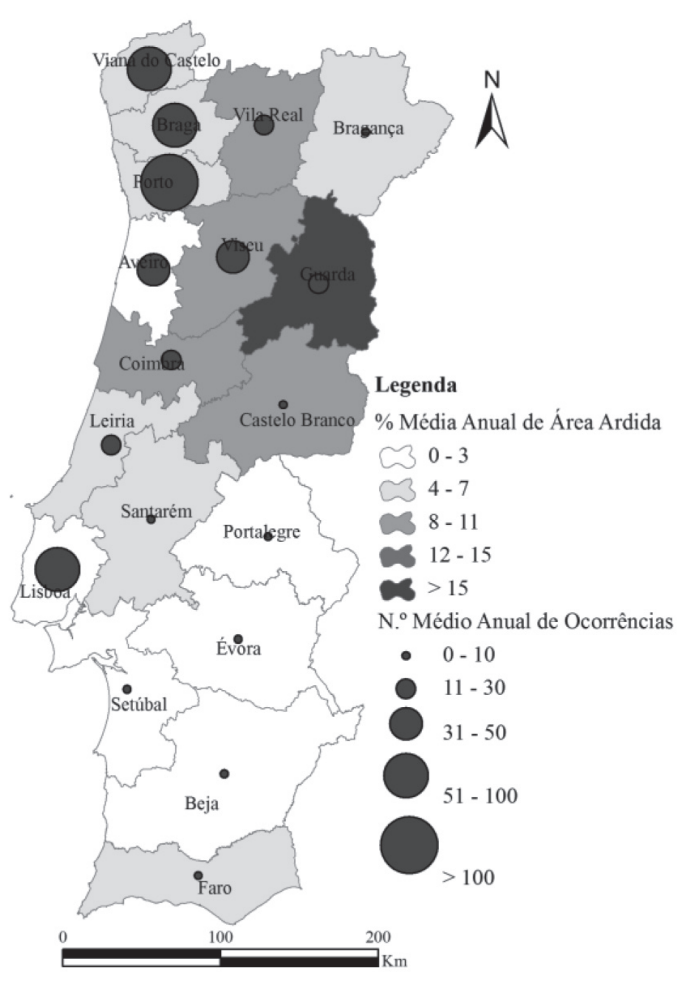

Figura 4

Distribuição espacial da percentagem média anual de área ardida e do número médio anual de ocorrências por $\mathrm{km}^{2}$ em Portugal Continental, por distrito, no período de 1980-2010.

Fonte dos dados: Autoridade Florestal Nacional.

Por outro lado, a redução dos efetivos e a alteração da estrutura da população conduziu a que inúmeros espaços que antes estavam devidamente geridos e agricultados, servindo muitas vezes como áreas de contenção dos incêndios, tivessem sido abandonados e, atualmente, constituam grandes manchas contínuas de espaço florestal, por vezes com grande densidade de combustível, sem qualquer tipo de gestão, o que obviamente facilita a propagação dos incêndios.

Todos estes fatores levaram a uma significativa alteração das espécies autóctones, em que, num passado não muito longínquo, predominavam as folhosas de crescimento lento, com destaque para os Carvalhos (Quercus spp) e o Castanheiro (Castanea sativa), e que começaram por ser substituídas por resinosas, essencialmente pinheiro bravo (Pinus Pinaster), o qual, por sua vez, em resultado dos sucessivos incêndios, ou deixa os espaços florestais incultos, ocupados por mato, ou, então, tem cedido o seu lugar a folhosas de crescimento rápido, como é o caso do eucalipto (Eucalyptus globulus), o que também se traduz em alterações na paisagem.
É óbvio que, quando procuramos explicar os incêndios florestais que ocorrem em Portugal, além destas causas indiretas e de outras, como sejam as condições meteorológicas que analisaremos a seguir, não podemos deixar de considerar que o elevado número de ocorrências que está intimamente associado a causas humanas, nomeadamente, as negligentes, tais como o uso do fogo, ou as causas acidentais e estruturais, e, também, as intencionais, como é o caso do incendiarismo, além daquelas que, por terem ficado indeterminadas, se consideram desconhecidas. Como, por outro lado, as naturais ocupam uma pequena percentagem, parece ser possível reduzir substancialmente o número de ignições, uma vez que estas dependem, quase exclusivamente, da vontade do ser humano.

Por sua vez, a extensão queimada está indiretamente associada a determinadas condições naturais, mais difíceis de alterar, mas em que também é possível intervir, designadamente no que diz respeito à gestão do combustível e ao ordenamento do espaço florestal, pelo que, a substancial redução das áreas queimadas passa também por uma maior intervenção no espaço florestal.

\section{Condições meteorológicas e incêndios florestais}

As condições meteorológicas podem favorecer ou dificultar tanto a ignição como a progressão dos incêndios. As variáveis que mais interferem ou que mais vão condicionar as ocorrências de incêndios florestais são a temperatura e a humidade relativa do ar, bem como a precipitação. Por sua vez, aquelas que mais influenciam a progressão dos incêndios são temperatura elevada e baixa humidade relativa do ar e vento, moderado a forte, do quadrante Este.

\subsection{Condições Meteorológicas: precipitação, temperatura e humidade relativa do ar, no período de 1971 a 2010}

A análise de alguns valores destas variáveis pode ajudar a compreender como influenciam ou não o comportamento dos incêndios florestais.

Em termos anuais, no período compreendido entre 1971-2010, a temperatura média anual, apresentou uma tendência para um certo aumento, particularmente visível quando comparamos a evolução dos valores anuais com o valor da normal climatológica $\left(15,18^{\circ} \mathrm{C}\right)$ nesse período (Figura 5$)$. A década iniciada em 1971 foi a que registou valores mais baixos de temperatura média anual do ar, com o ano de 1972, no 


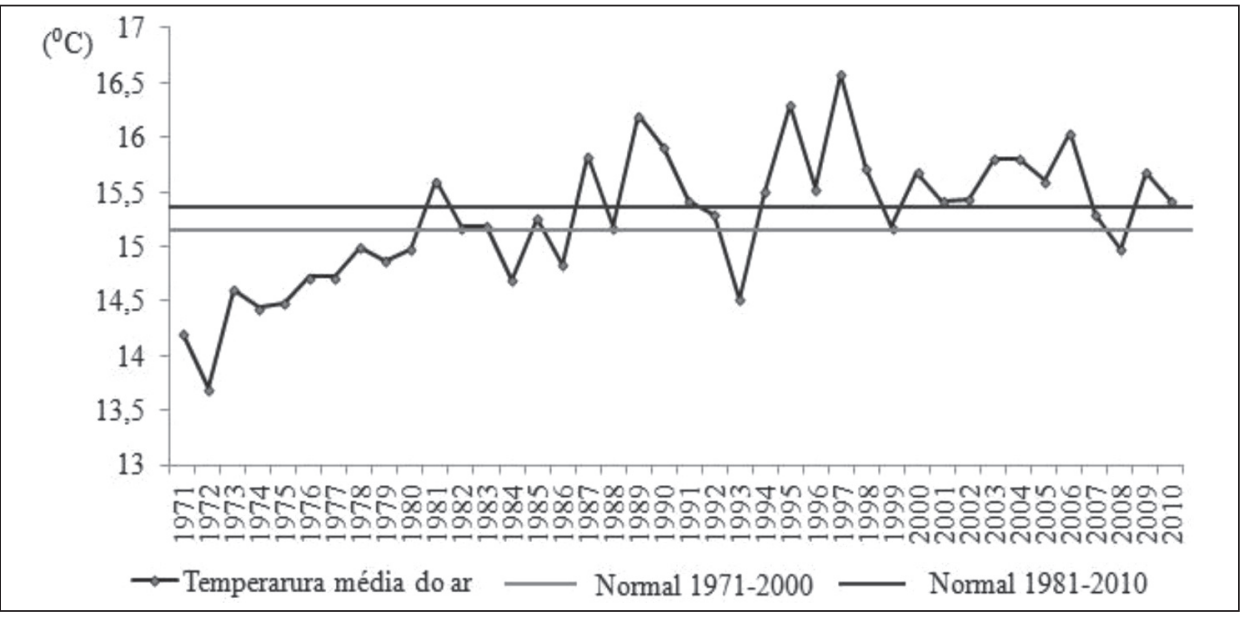

Figura 5

Variabilidade anual da temperatura média em Portugal Continental no período de 1971-2010, comparativamente com o valor da normal Climatológica de 1971-2000 e de 1981-2010.

Fonte: Instituto de Meteorologia, com modificações.

início da década, a registar a temperatura mais baixa, inferior a $14^{\circ} \mathrm{C}$, e o ano de 1978 , no final da década, a registar a temperatura mais elevada, $15^{\circ} \mathrm{C}$. Todos os anos desta primeira década registaram valores de temperatura média anual inferiores aos da normal climatológica do período considerado.

A década iniciada em 1981 correspondeu a um período de mudança, com vários anos, alguns deles consecutivos, a registarem valores de temperatura mais elevados do que o valor normal. Logo em 1981 foi registada uma temperatura de mais de $15,5^{\circ} \mathrm{C}$, seguida de uma descida até o ano de 1984, a partir do qual volta a aumentar, entre avanços e recuos, até 1989, ano em que se atinge a terceira temperatura mais elevada do período em análise. 0 início da década seguinte foi marcado por nova descida da temperatura média anual, até 1993, ano em que se inverteu essa tendência e, logo dois anos depois, em 1995, registou-se a segunda temperatura mais elevada da série, superior a $16^{\circ} \mathrm{C}$.

A década seguinte, até 2010, foi marcada por uma variação menos significativa, com a ponta final a apresentar uma certa tendência para descida, mais assinalada nos anos 2007 e 2008, com este a situar-se abaixo da normal climatológica de 1971-2010.

Para além da temperatura, também a humidade relativa do ar adquire uma especial importância, enquanto variável condicionante da ocorrência de incêndios florestais, sobretudo na ausência da precipitação que a origina, pois, quando esta ocorre, interfere com o teor de humidade da vegetação. Deste modo, na presença de um grande teor de humidade a vegetação muito dificilmente entra em combustão e, pelo contrário, a falta de precipitação traduz-se na secura da vegetação, o que aumenta a sua inflamabilidade, principalmente no que respeita aos combustíveis finos, tornando-os um bom combustível para arder com mais facilidade e rapidamente.

Deste modo, com vista à análise da precipitação total ocorrida em termos anuais, no período 1971-2010, foi utilizado um gráfico, disponibilizado pelo Instituto de Meteorologia, com o desvio do total de precipitação anual em relação ao valor da normal climatológica de 1971-2010 (Figura 6).

Observa-se que houve uma alternância de anos com mais precipitação relativamente a outros com valores mais reduzidos, com a década de 2000 a registar os valores mais reduzidos, sendo o ano de 2005 aquele que deteve o menor valor de precipitação, com quase $400 \mathrm{~mm}$ a menos do que seria "normal", ano que coincidiu com o de maior número de ocorrências de incêndios florestais. Todavia, esta circunstância não permite concluir que existe uma relação direta entre a variação da precipitação e a ocorrência de incêndios florestais.

$\mathrm{Na}$ realidade, quando averiguamos outros anos que corresponderam aos maiores valores de ocorrências de incêndios florestais e às maiores áreas ardidas verificamos que nem sempre temos valores reduzidos de precipitação. Por exemplo, os anos de 1989 e de 1995, que se distinguiram pelo número de ocorrências, foram também anos em que a precipitação total anual teve valores superiores ao valor médio, ou o ano de 2003 e o de 1985, que se distinguiram pelas grandes áreas ardidas, também apresentaram quantitativos plu- 


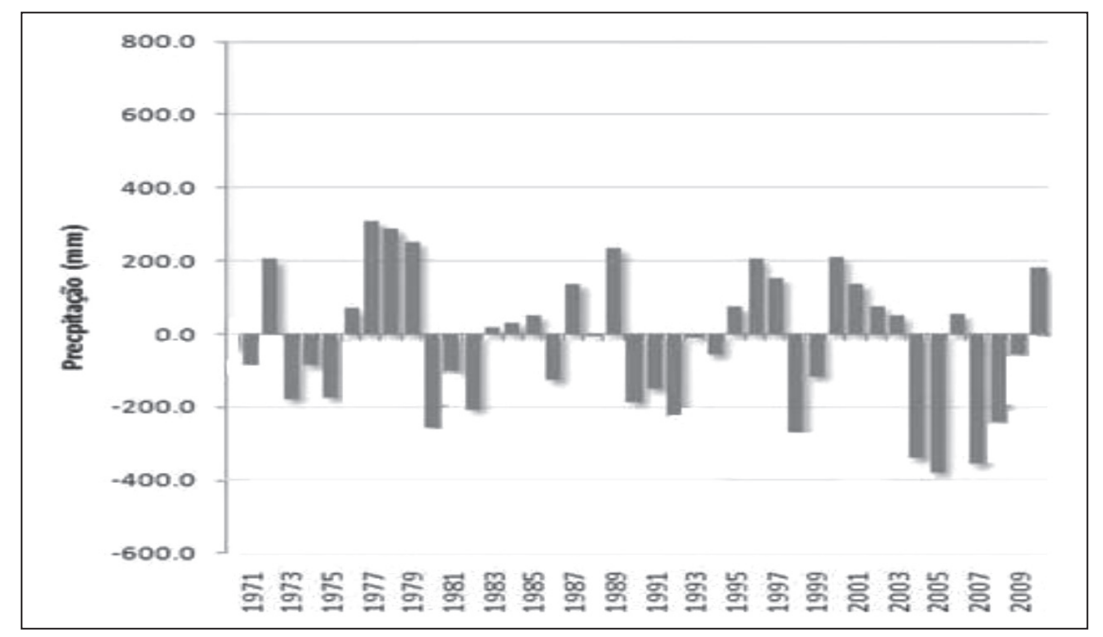

Figura 6

Desvio do total da precipitação anual para Portugal Continental, em relação ao valor da normal climatológica de 1971-2000, no período entre 1971-2010.

Fonte: Instituto de Meteorologia.

viométricos superiores aos normais. Em contrapartida os anos de 2007 e de 2008, que apresentaram das mais reduzidas áreas ardidas, também detêm valores bastante mais reduzidos de precipitação.

Esta situação levou-nos a proceder a uma análise dos valores mensais de ambas as variáveis, pois mais do que os valores anuais, é a sua distribuição diária, que mais condiciona a ocorrência e o desenvolvimento dos incêndios florestais.

\subsection{Condições meteorológicas favoráveis à ocorrência e progressão de Incêndios florestais: os anos críticos de 2003 e 2005}

Sabemos que em Portugal Continental, as características meteorológicas, associadas a um clima temperado mediterrâneo, facilitam a ocorrência de incêndios florestais. As razões decorrem de verões com temperaturas elevadas e uma precipitação reduzida ou nula, forte evaporação e vegetação facilmente inflamável, devido ao baixo teor de humidade, resultante da secura estival.

Do ponto de vista do comportamento dos incêndios, nomeadamente no que respeita à sua propagação, o vento é o principal fator meteorológico interveniente, sobretudo quando sopra do quadrante Este.

Outras situações meteorológicas favoráveis correspondem a condições meteorológicas especiais, sobretudo quando ocorrem nos meses de verão, como por exemplo as ondas de calor e as secas meteorológicas, criando situações mais críticas em termos de incêndios. Os anos de 2003 e de 2005, os piores da história portu- guesa em termos dendrocaustológicos, foram escolhidos por, respetivamente, corresponderem a cada uma dessas situações, o que permite fazer uma abordagem mais pormenorizada das situações meteorológicas que ocorreram e que ajudam a explicar o que sucedeu.

\subsubsection{Ano de 2003}

Em termos de incêndios florestais, o ano de 2003 caracterizou-se por apresentar a maior área ardida desde que há registo, correspondendo a 425.839,1 hectares devastados pelas chamas (Instituto de Conservação da Natureza e das Florestas, 2012). No entanto, o número de incêndios rondou os valores mais baixos dos oito anos anteriores, num total de 26.219 ocorrências.

Relativamente à distribuição espacial do número de ocorrências para Portugal Continental, estas tiveram a sua maior expressão no distrito do Porto, com 7715, seguindo-se os distritos de Braga e de Lisboa com 4376 e 2399 ocorrências respetivamente (Instituto de Conservação da Natureza e das Florestas, 2012). Por outro lado, o distrito de Évora, com 68 ocorrências, foi o que registou o valor mais baixo, seguindo-se os distritos de Portalegre, Beja e Faro, o que corresponde ao padrão normal de distribuição das ocorrências.

Pelo contrário, em termos da repartição espacial das áreas ardidas verificou-se um padrão diferente do habitual em anos anteriores (Figura 7). Assim, em termos de área ardida, as áreas mais afetadas corresponderam a distritos onde habitualmente arde pouco, nomeadamente, em Portalegre, Faro e Beja, que perderam, nesse ano, respetivamente 69.348, 57.188 e 

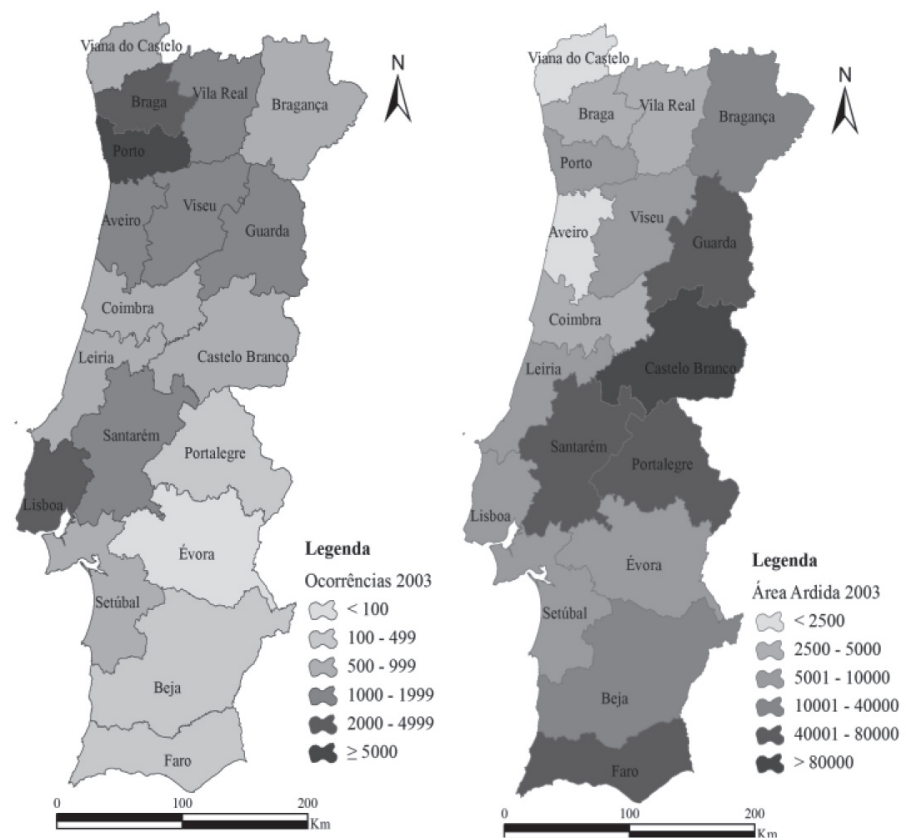

Figura 7

Distribuição do número de ocorrências (à esquerda) e da área ardida, (à direita), por distrito, em Portugal Continental, no ano de 2003.

Fonte dos dados: Autoridade Florestal Nacional.

15.381 hectares de floresta. 0 distrito de Castelo Branco registou a maior área ardida, com 90.253 hectares. Em contrapartida, nos distritos da Guarda e Viseu, os valores da área ardida foram mais baixos do que em anos anteriores. Também se registarem menores extensões ardidas do que habitualmente nos distritos de Aveiro, Vila Real, Braga, Coimbra e Viana do Castelo. Desta feita, as áreas mais afetadas correspondem especialmente ao Centro-Sul e Sul, ao contrário do que habitualmente sucede (Figura 7).

Ao nível da distribuição mensal das ocorrências e das áreas ardidas verificamos que houve uma maior concentração de ambas no mês de agosto, que registou 6498 ocorrências e 280.550 hectares ardidos (Instituto de Conservação da Natureza e das Florestas, 2003). Nos meses de junho, julho e setembro o número de incêndios foi semelhante, tendo-se situado à volta de 3200 ocorrências (Instituto de Conservação da Natureza e das Florestas, 2003). Nos restantes meses do ano só maio apresentou um número considerável de ocorrências, 1613.

Em termos de área ardida, os meses de julho e de setembro foram os que se seguiram ao mês de agosto. Os restantes meses do ano apresentaram valores de área ardida bastante mais reduzidos (Figura 8).

Do ponto de vista meteorológico, os meses de agosto e setembro do ano de 2003 apresentaram-se mais quentes do que é normal (Figura 9), o que, de certo modo, ajuda a explicar a dimensão das áreas ardidas, mas não justifica tudo, tanto mais que, nas regiões tradicionalmente mais problemáticas, eles foram um pouco mais frescos e húmidos do que em anos anteriores (LOURENço, 2007: 33).

A distribuição dos valores mensais da precipitação confirmam esta hipótese, uma vez que, nos meses de julho e agosto foram também superiores ao normal (Figura 10), não contribuindo para a explicação das grandes áreas ardidas no mês de agosto apenas por causas meteorológicas.

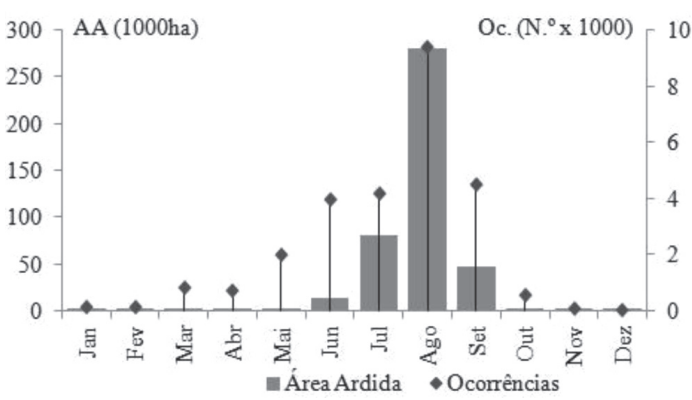

Figura 8

Evolução mensal do número de ocorrências e da área ardida toral em hectares, no ano de 2003.

Fonte dos dados: Autoridade Florestal Nacional. 


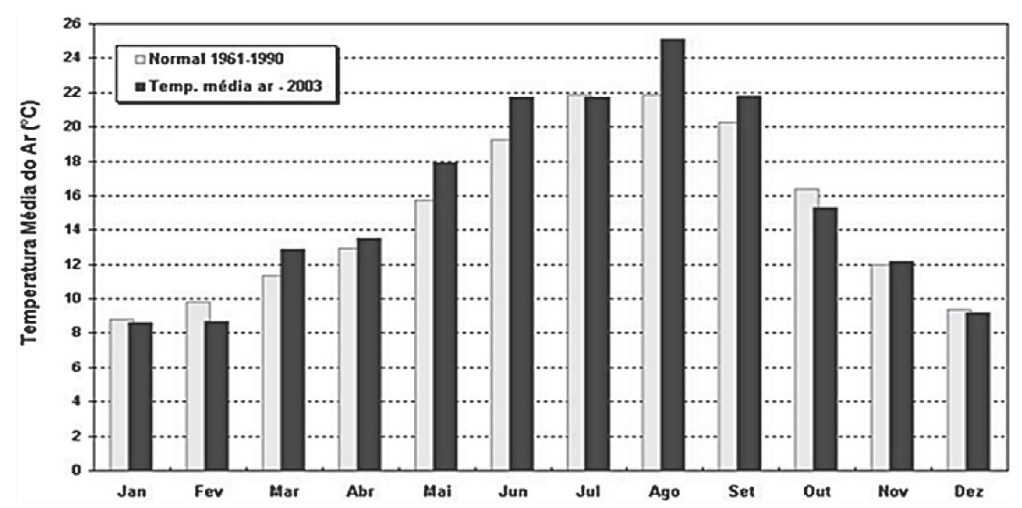

Figura 9

Temperatura média mensal do ar e sua relação com os valores da normal climatológica (1961-1990). Fonte: Instituto de Meteorologia.

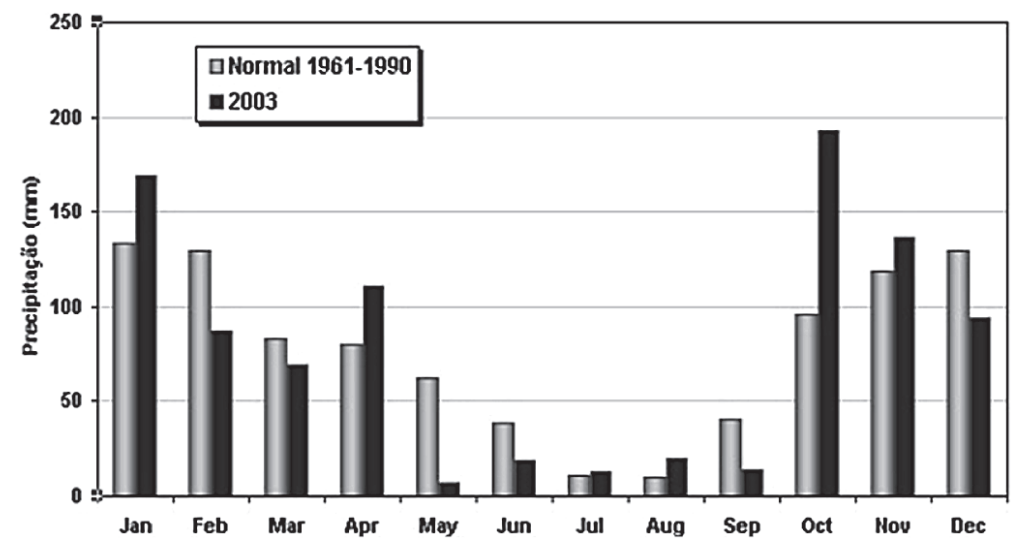

Figura 10

Distribuição da precipitação mensal durante o ano de 2003, comparativamente com o valor da normal climatológica (1961-1990).

Fonte: Instituto de Meteorologia.

Significativa, ainda, a precipitação registada no mês de outubro, que apresentando o valor máximo, bastante superior ao normal, o que é particularmente significativa pelas consequências que acarreta em termos de erosão dos solos após os incêndios florestais.

Deste modo, em termos de incêndios florestais, o período mais crítico correspondeu ao final do mês de julho e ao início do mês de agosto, devido ao estado de tempo, que, em certas regiões de Portugal Continental, foi, favorável ao desenvolvimento de incêndios. Com efeito, ocorreu uma massa de ar quente e seco, transportada na circulação conjunta de um anticiclone, que se estendia em crista do Sul dos Açores até ao Golfo da Biscaia, e de um vale depressionário, que se prolongava do Norte de África até à Península Ibérica, gerou uma onda de calor, entre 29 de julho e 14 de agosto, com duração de 16 a 17 dias em grande parte das estações meteorológicas do interior, sendo considerada a maior onda de calor desde que há registos (Figura 11) e que, em parte, ajuda a explicar o sucedido.

Assim, os 3 primeiros dias de agosto foram particularmente quentes, com temperaturas máximas superiores a $40^{\circ} \mathrm{C}$ em grande parte do território e com valores de temperatura mínima também muito elevados, por vezes superiores a $25^{\circ} \mathrm{C}$ e até $30^{\circ} \mathrm{C}$ (Figura 12). A humidade relativa foi também muito reduzida nalgumas regiões, por vezes, inferior a $20 \%$.

Este ano teve ainda a particularidade de registar um número anormalmente elevado de descargas elétricas (faíscas), provenientes de trovoadas secas, nos dias 1 e 2 de agosto (Figura 13), tendo, muitos desses raios sido os responsáveis, por parte substancial do elevado 


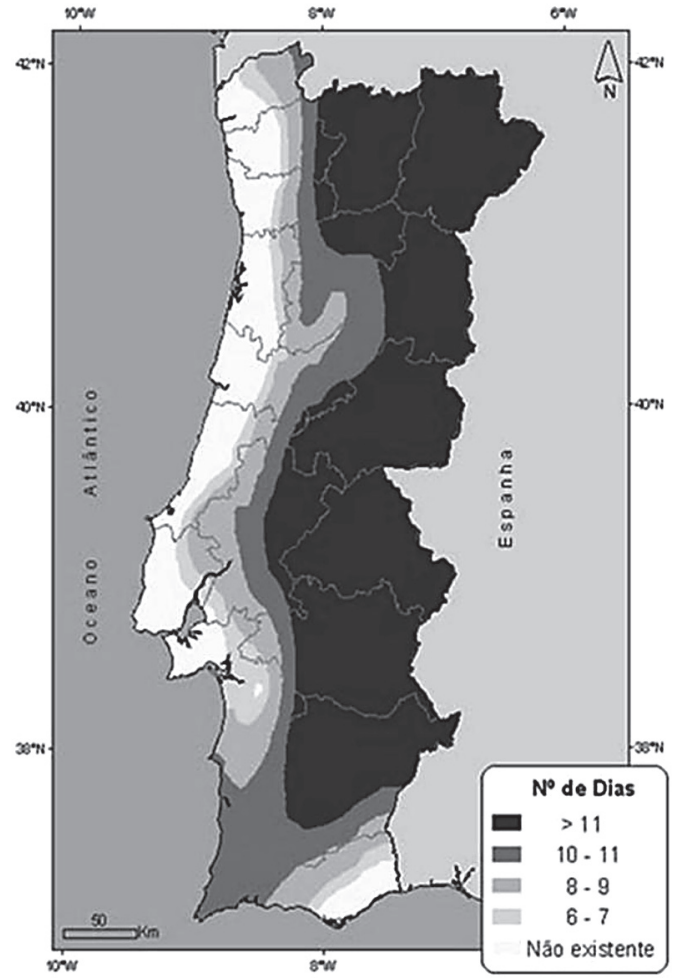

Figura 11

Duração da onda de calor registada entre 29 de julho e 14 de agosto de 2003.

Fonte: Instituto de Meteorologia.

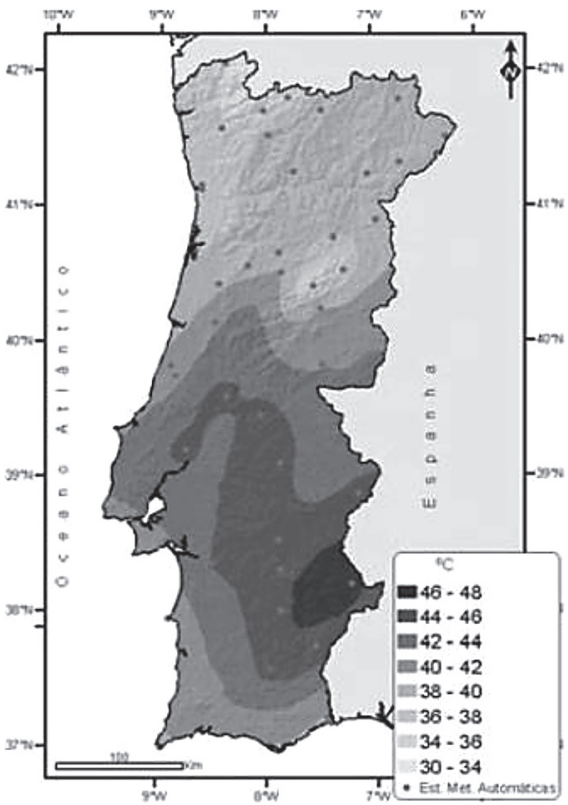

número de ignições verificadas, pelo que a semana de 28 de julho a 3 de agosto foi a pior de que há memória, em termos de área queimada, superior a 240.000 hectares (LOURENço, 2007).

A conjugação, no início do mês de agosto, de diversas circunstâncias favoráveis à ignição e progressão de incêndios florestais, tais como a onda de calor registada, os valores elevados de temperaturas máxima e mínima, a baixa humidade relativa do ar e as trovoadas secas, especialmente em áreas que não correspondem às tradicionalmente mais afetadas por incêndios, contribuíram para os elevados valores de ocorrências e, sobretudo, para a gigantesca área ardida. A situação poderia ter sido ainda bem mais grave se, ao contrário do que sucedeu nesse período, a região NW não tivesse tido um risco de incêndio florestal reduzido. Se, porventura, se encontrasse também com risco elevado e muito elevado nesses dias, o resultado teria sido ainda bem mais desastroso.

A razão da existência de grandes áreas ardidas em locais não habituais, pode, ainda, associar-se ao facto de, nestas situações, a população não se encontrar preparada para enfrentar as situações de perigo, existindo uma certa falta de consciência para as medidas de gestão a tomar fora da época crítica, nomeadamente com a limpeza da área em torno das habitações e uma melhor gestão do espaço florestal, que facilitasse a ex-

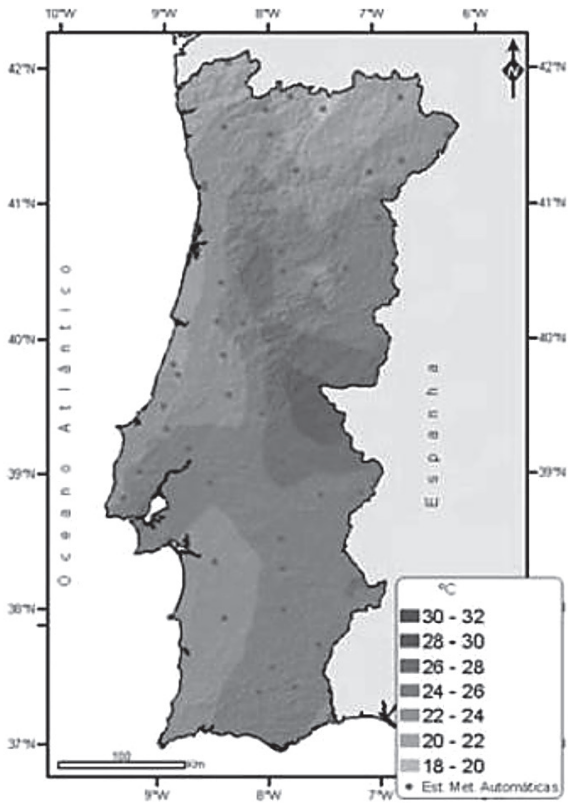

Figura 12

Distribuição espacial das temperaturas máxima diária (à esquerda) e mínima diária (à direita), de 1 a 3 de agosto de 2003.

Fonte: Instituto de Meteorologia. 
tinção dos incêndios e a atuação dos meios de combate (LOURENÇO, 2007).

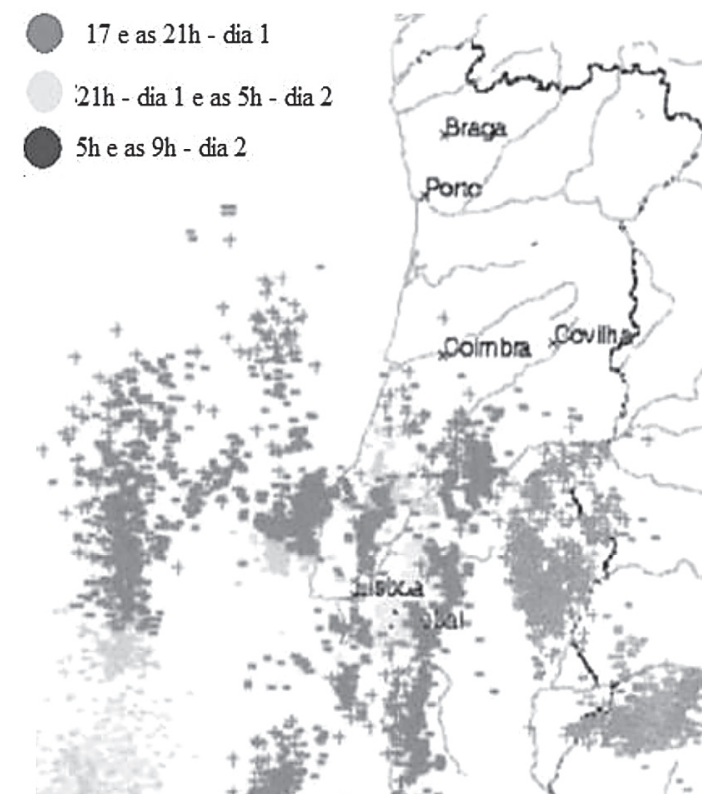

Figura 13

Distribuição espacial das descargas elétricas atmosféricas nos dias 1 e 2 de agosto de 2003.

Fonte: MENDES, 2003.

\subsubsection{Ano de 2005.}

0 ano de 2005 foi outro ano problemático em termos de incêndios florestais, apresentando-se como aquele que deteve o maior número de ocorrências, desde que há registo, com 35.824. A área ardida foi também extensa, apesar de inferior à do ano de 2003, correspondendo a cerca de 340.000 hectares ardidos, de acordo com os dados disponibilizados pelo Instituto de Conservação da Natureza e das Florestas.

Em termos da distribuição espacial verificou-se, ao nível das ocorrências, uma maior concentração no distrito do Porto, com mais de 7000 ignições, seguindose os distritos envolventes de Braga, Aveiro, Viseu, Vila Real, e também o distrito de Lisboa, com mais de 2500 ocorrências, querendo isto dizer que, preferencialmente, os maiores valores de ocorrências se encontram juntos dos grandes centros urbanos. Por outro lado, ainda em termos de ocorrências, os distritos menos afetados foram aqueles que se encontram na região sul, nomeadamente Évora, Beja, Faro e Portalegre (Figura 14).

Relativamente às áreas ardidas, todos os distritos do Norte do território Continental foram afetados, com destaque para o distrito de Coimbra, que, neste ano, apresentou o maior valor de área ardida, com mais de 48.000 hectares incinerados de floresta. Neste ano foram os distritos da região sul os menos afetados, ve-
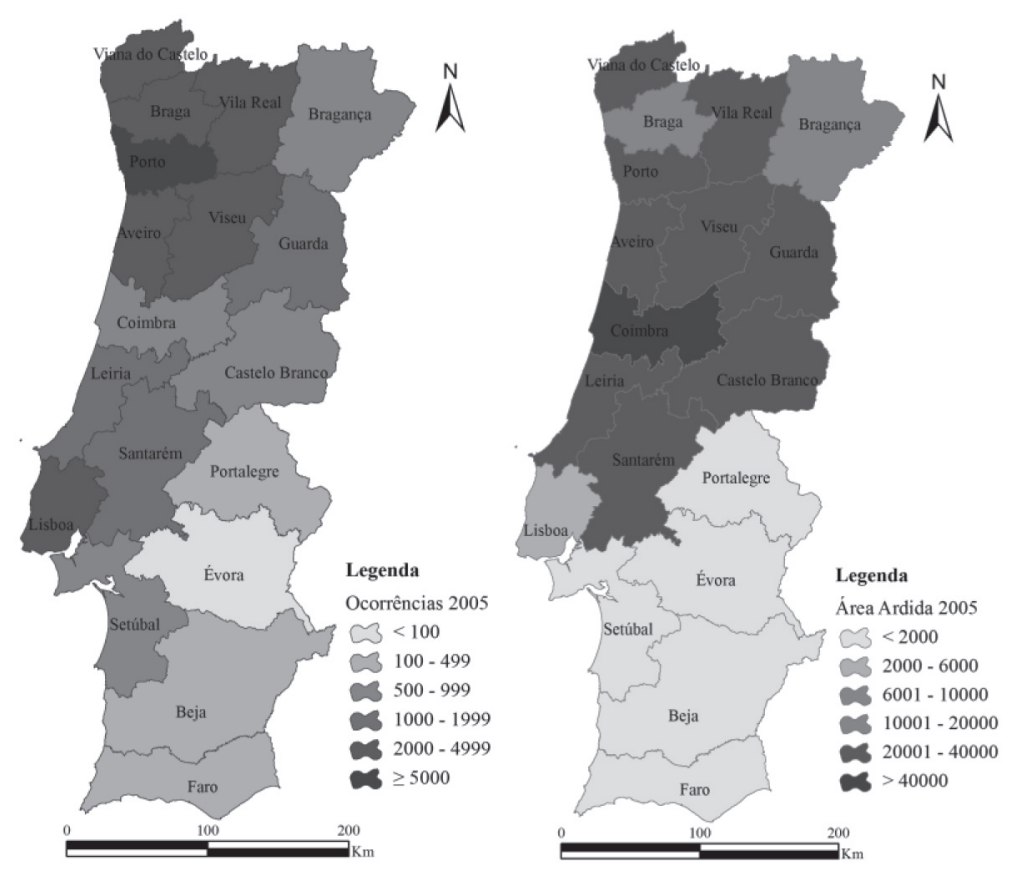

Figura 14

Distribuição, por distrito, do número de ocorrências (à esquerda) e das áreas ardidas em hectares (à direita), em Portugal Continental, no ano de 2005.

Fonte dos dados: Autoridade Florestal Naciona 
rificando-se o regresso aos padrões tradicionais, pois as maiores áreas ardidas voltaram a registar-se na região Centro e Norte de Portugal (Figura 14).

Do ponto de vista mensal, o mês de agosto foi o mais problemático, pois concentrou os maiores valores tanto de ocorrências como de área ardida, respetivamente cerca de 9670 e 202.353 (ha), Este ano teve a particularidade de, no início, em janeiro e especialmente em fevereiro e março, se terem registado valores consideráveis de número de ocorrências, com março a ultrapassar 3200 ignições, sem que, apesar desse elevado número, se tenham registado áreas ardidas significativas (Figura 15).

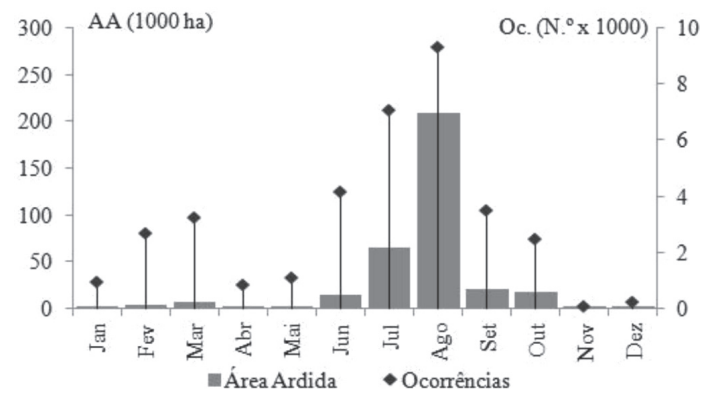

Figura 15

Distribuição mensal da área ardida, em hectares, e do número de ocorrências, no ano de 2005.

Fonte dos dados: Autoridade Florestal Nacional.

Em termos de condições meteorológicas, o ano de 2005 foi caracterizado por anomalias positivas da temperatura média, relativamente ao valor normal de 1961-1990, especialmente nos meses de verão, que foi o mais quente registado nos últimos 75 anos, com duas ondas de calor no mês de junho, que afetaram sobretudo a região Este do País. Nos meses do início e fim do ano, os valores de temperatura foram mais baixos do que o normal (Figura 16), especialmente no mês de fevereiro, em virtude de neste mês ter também sido registada uma vaga de ar frio.

No que diz respeito à precipitação, o mês de outubro foi o único a registar quantitativos superiores ao valor da normal 1961-1990 (Figura 17). Em termos anuais, registou-se o valor mais baixo de precipitação, desde 1931.

A conjugação destas duas situações concorreu para que em 2005 se tivesse registado uma seca meteorológica bastante acentuada, durante quase todo o ano, tendo sido considerada pelo Instituto de Meteorologia como "Severa e Extrema" nos meses de junho a setembro e em grande parte do território Continental (Figura 18), correspondendo ao período de seca com maior extensão territorial e mais intenso dos últimos 60 anos, com início ainda no ano de 2004. Esta terá sido a principal razão para que, logo nos meses de janeiro, fevereiro e março tivessem ocorrido numerosos incêndios. Com a continuidade desta situação de seca nos meses seguintes, a que se associou o posterior e progressivo aumento da temperatura do ar e, principalmente, a diminuição da sua humidade, criaram-se condições favoráveis à ignição de numerosas ocorrências de incêndios florestais, bem como à fácil progressão dos mesmos.

Além do fator meteorológico, razão de ser deste artigo, um outro aspeto que contribuiu para o desenvolvimento de alguns grandes incêndios decorreu do facto de eles se desenrolarem em espaços urbano-florestais, o que, devido à dispersão de habitações e de pequenas unidades industriais no interior da mancha florestal, bem como à elevada carga de combustível existente em muitas das áreas envolventes onde se acumulam mate-

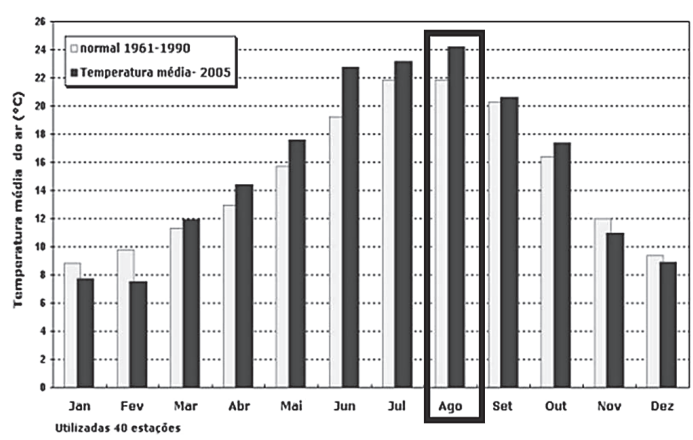

Figura 16

Distribuição da temperatura média mensal do ar em Portugal continental, no ano de 2005 e sua relação com a normal (1961-1990). Fonte: Instituto de Meteorologia.

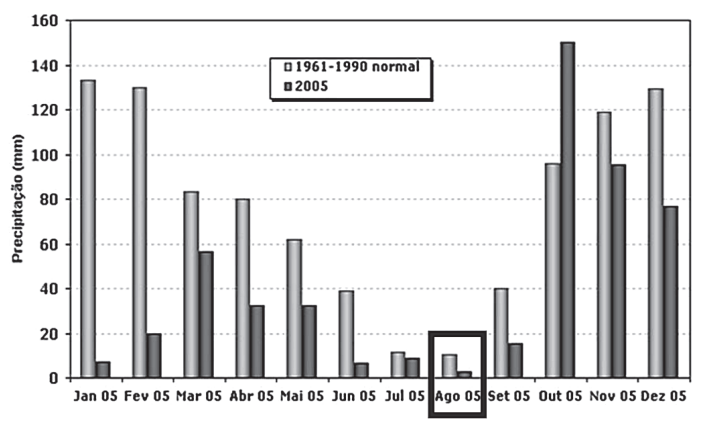

Figura 17

Evolução da precipitação mensal e sua relação com o valor normal (1961 1990).

Fonte: Instituto de Meteorologia. 


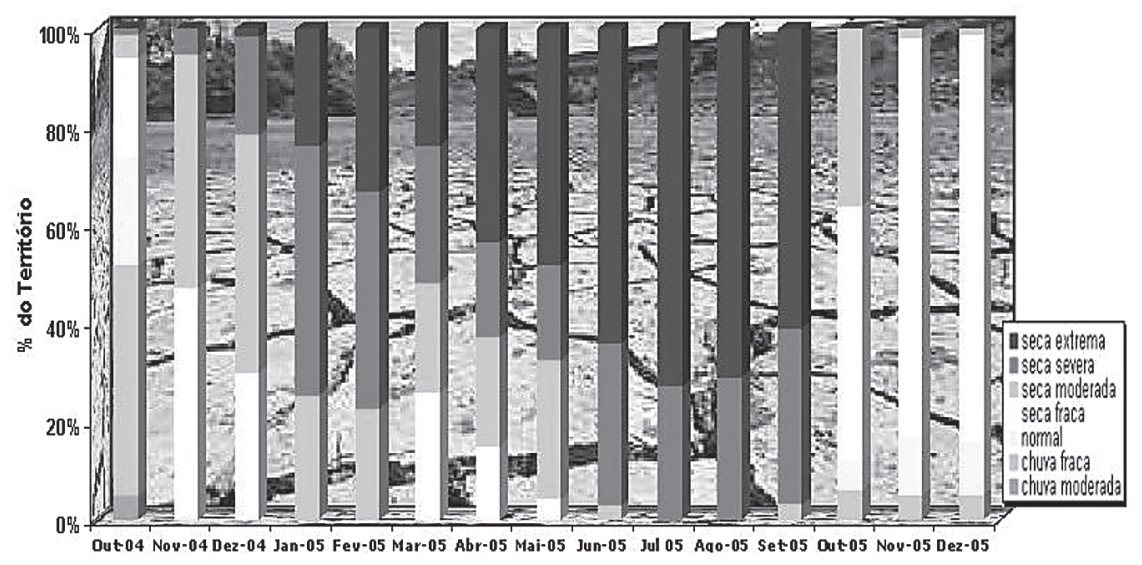

Figura 18

Percentagem mensal de território distribuído pelas diferentes classes de seca meteorológicas (out. 2004 - dez. 2005). Fonte: F. SANTO, 2006.

riais inflamáveis das mais diversas naturezas, cujos depósitos, quase sempre ilegais, diminuem as condições de segurança (LOURENço, 2006b e 2007), muito contribuiu para a problemática e mediatismo que algumas situações atingiram.

\subsection{Condições meteorológicas desfavoráveis ao desenvolvimento de incêndios florestais. O exemplo do ano de 2007}

Até aqui, temos vindo a enfatizar o papel das condições meteorológicas mais favoráveis para a ocorrência e progressão dos incêndios florestais. Apesar da sua variabilidade, em termos mensais, elas concentram-se habitualmente nos meses de julho, agosto e setembro, pelo que estão mais associados ao fenómeno dos incêndios florestais.

Todavia, sempre que nesses meses se registam quantitativos pluviométricos superiores à normal, mesmo que nos restantes meses sejam inferiores, como foi o caso de 2007 (Figura 19), nesses anos a gravidade dos incêndios é substancialmente reduzida.

De facto, este ano caracterizou-se pela maioria dos meses terem registado totais pluviométricos bem inferiores aos normais, situação favorável aos incêndios, com exceção dos meses de junho, julho e agosto, que se apresentaram pluviosos, com valores a ultrapassar os normais (Figura 19), o que se revelou determinante para contrariar a situação de seca dos meses anteriores.

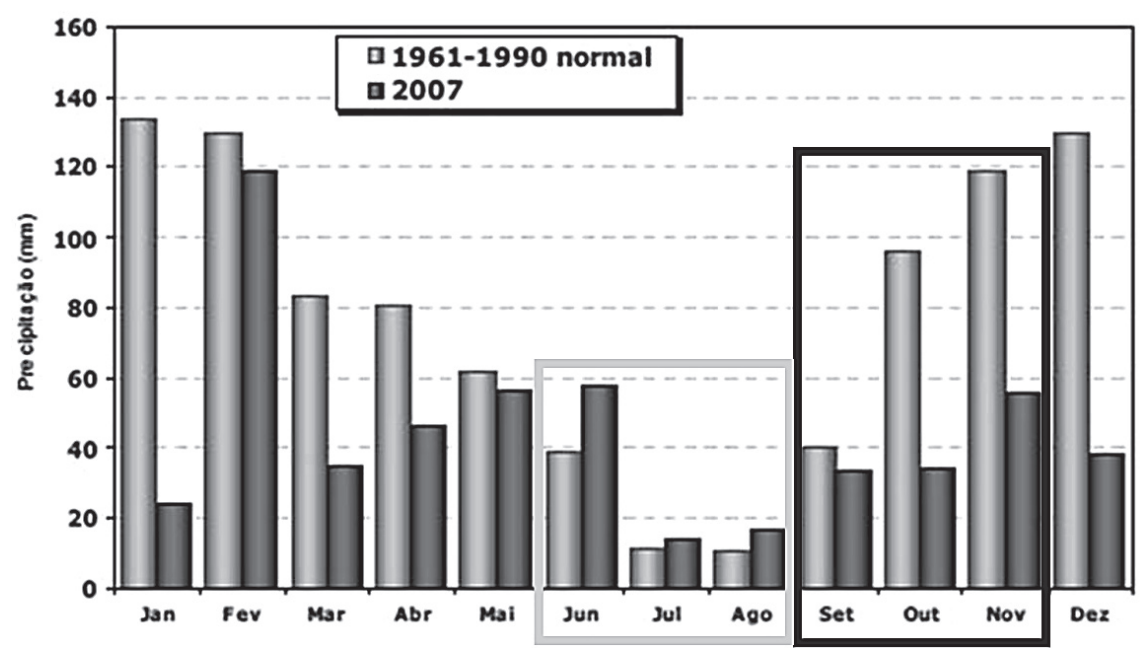

Figura19

Precipitação mensal em 2007, comparativamente com o valor normal (1961-1990).

Fonte: Instituto de Meteorologia, com adaptações. 
Por sua vez, as condições meteorológicas responsáveis pela precipitação também contribuíram para que as temperaturas desses meses tivessem sido inferiores às normais (Figura 20), situação que se revelou desfavorável aos incêndios florestais.

Com efeito, desde 1988 que estes meses não registavam valores tão baixos da temperatura média do ar, o que contribui para que também não tivesse ocorrido nenhuma onda de calor, situação que também já não se verificava desde o ano de 1997.

Estes três meses, de junho a agosto, também se distinguiram por terem apresentado anomalias negativas, ou seja, as respetivas temperaturas máximas e mínimas foram inferiores ao valor normal. Por sua vez, foi o mês de novembro que registou as maiores anomalias, tanto positiva, como negativa, respetivamente das temperatura máxima e mínima do ar (Figura 21), situação que se deveu à influência de um Anticiclone localizado a OSO da Inglaterra, que, conjuntamente com uma depressão localizada no Norte de África, originou valores de temperatura acima dos normais para a época do ano, determinando um agravamento do risco meteorológico, que se traduziu num elevado número de ocorrências de incêndios florestais, que registou o valor mais elevado desse ano (Figura 22), contrariando a tendência mais habitual.
Com efeito, como se demonstra, apesar dos incêndios florestais terem origem quase exclusivamente humana, são as condições meteorológicas que ditam as regras que têm a ver com maior ou menor facilidade de ignição, bem como de progressão.

Em suma, os meses de junho a agosto, por terem apresentado temperaturas mais baixas do que o normal e ao serem excecionalmente chuvosos, conferiram à vegetação teores de humidade mais elevados do que os habituais nestes meses, o que desfavoreceu a ocorrência de numerosos incêndios florestais, dada a relação inversa entre estas variáveis. Assim, maiores quantitativos de precipitação, temperaturas do ar mais amenas, a que se associa uma humidade relativa mais elevada, proporcionam maior humidade aos combustíveis e, por conseguinte, condições ideais para a redução substancial de incêndios (Figura 23).

Por outro lado, os meses de setembro, outubro e novembro, apresentaram um maior número de incêndios do que o habitual porque, também ao contrário do que costuma suceder, registaram precipitações fracas $e$ temperaturas, média e máxima, do ar mais elevadas do que o normal. Aliás, o mês de setembro registou a temperatura mínima média mais elevada do ano e o mês de novembro, na sua primeira quinzena (dias 2 a 9),

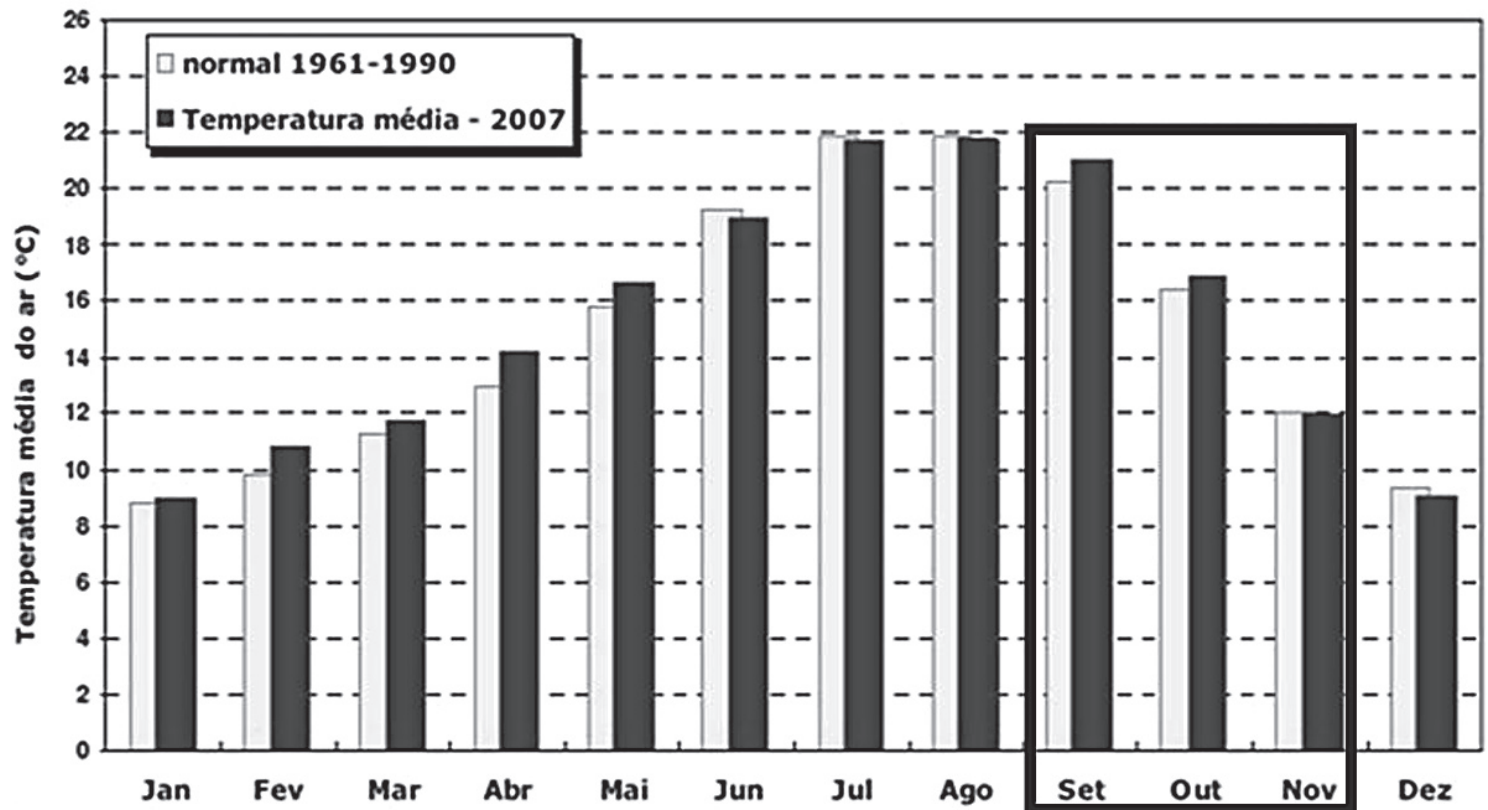

Figura 20

Temperatura média do ar em Portugal continental, em 2007, e sua relação com o valor normal (1961-1990).

Fonte: Instituto de Meteorologia, com adaptações. 


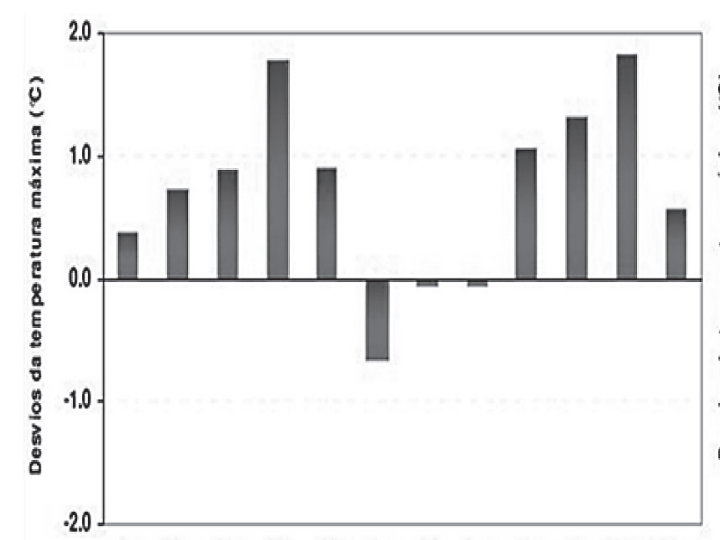

Jan Fev Mar Abr Mai Jun Jul Ago Sel Out Nov Dez

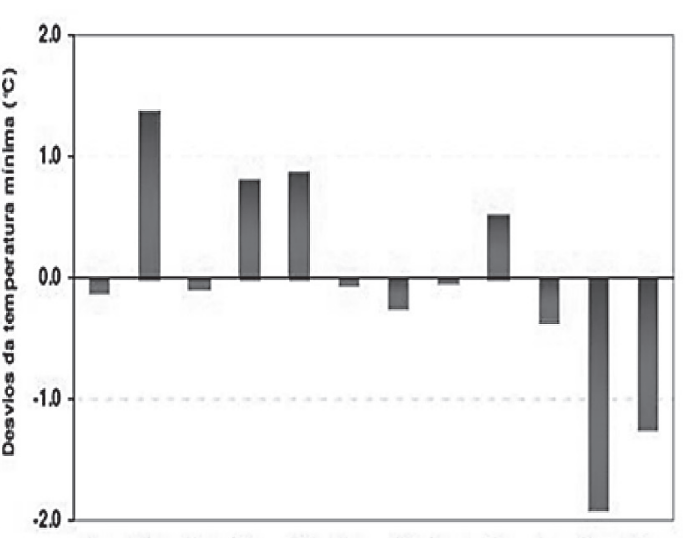

Jan Fev Mar Abr Mai Jun Jul Ago Set Out Nov Dez

Figura 21

Anomalias da média da temperatura máxima (à esquerda) e da temperatura mínima (à direita), do ar, em relação à normal 1961-1990. Fonte: Instituto de Meteorologia.

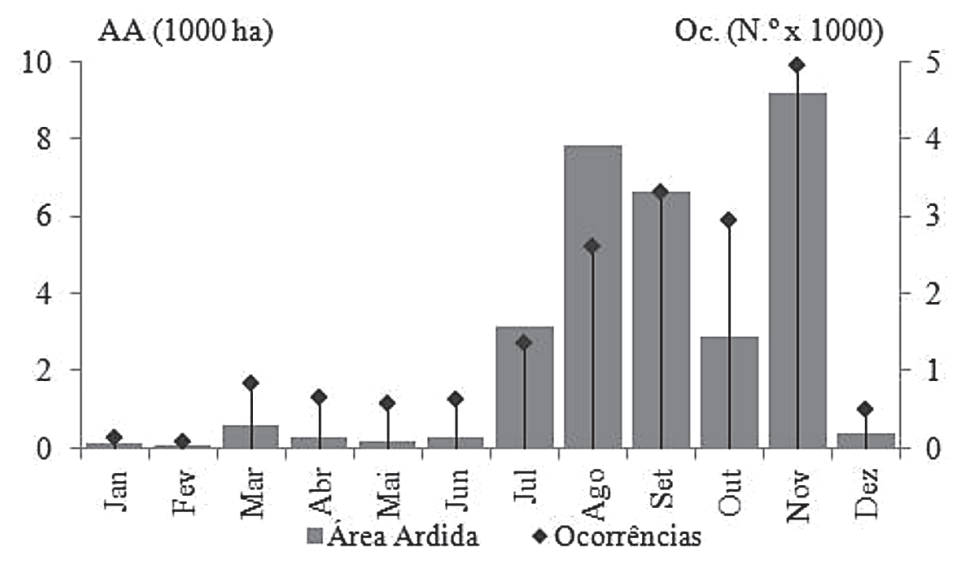

Figura 22

Número total de ocorrências e de área ardida em hectares, por mês, para Portugal continental, no ano de 2007.

Fonte dos dados: Autoridade Florestal Nacional.

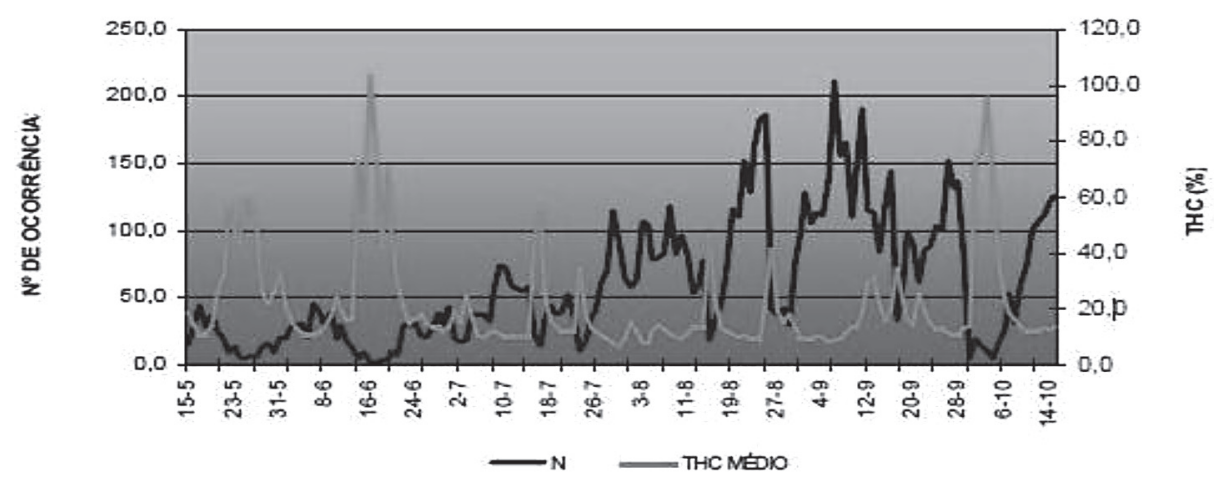

Figura 23

Relação entre o número de ocorrências e o THC (Teor de Humidade dos Combustíveis) médio diário, entre 15 de Maio e 15 de Outubro de 2007.

Fonte: Instituto de Meteorologia. 
registou uma onda de calor, que se estendeu a grande parte das regiões Norte e Centro.

Assim, devido à reduzida precipitação, estes meses apresentaram-se bastante secos, com destaque para o mês de novembro, que registou menos de $50 \%$ da precipitação normal, tendo levado a que, nesse mesmo mês, $97 \%$ do território continental tivesse apresentado seca meteorológica, a qual, naturalmente, se transmitiu aos combustíveis.

Não tivessem sido estas condições meteorológicas excecionais, também nos meses de setembro a novembro, e o ano de 2007 teria ficado para a história como o melhor dos últimos trinta anos, no que a incêndios florestais diz respeito.

De facto, o ano de 2007 registou uma reduzida área ardida, com um total de, apenas, 32.595 hectares, sendo que 9829 corresponderam a povoamentos e 22.766 a mato e os distritos mais afetados foram os de Braga, Guarda e Vila Real. O número total de ocorrências, 18.722, também foi reduzido em comparação com outros anos (Figura 1), com os distritos do Porto, Braga e Lisboa a serem os mais afetados (Figura 24), tendo registado, no conjunto, mais de 8000 ocorrências, ou seja, mais de $40 \%$ do total.

Em termos mensais, este ano também foi diferente dos anteriores com a maior concentração de incêndios florestais nos meses de setembro, outubro e, sobretudo, novembro (Figura 22), ao contrário do que normalmente sucede, com os meses de jutho e agosto a registarem os valores mais elevados. Foi também no mês de novembro que se registou a maior área ardida, 9203 hectares (Figura 22), contudo uma área substancialmente inferior à dos anos anteriores e, muito em especial, à dos anos de 2003 e de 2005.

No entanto, mais do que a medidas preventivas ou de outra natureza, esta substancial redução de incêndios florestais em 2001 ficou a dever-se, essencialmente, para não dizer em exclusivo, às condições meteorológicas desfavoráveis que se fizeram sentir, em nos meses de julho e agosto. Em contrapartida, condições meteorológica favoráveis, nos meses de setembro, ou-
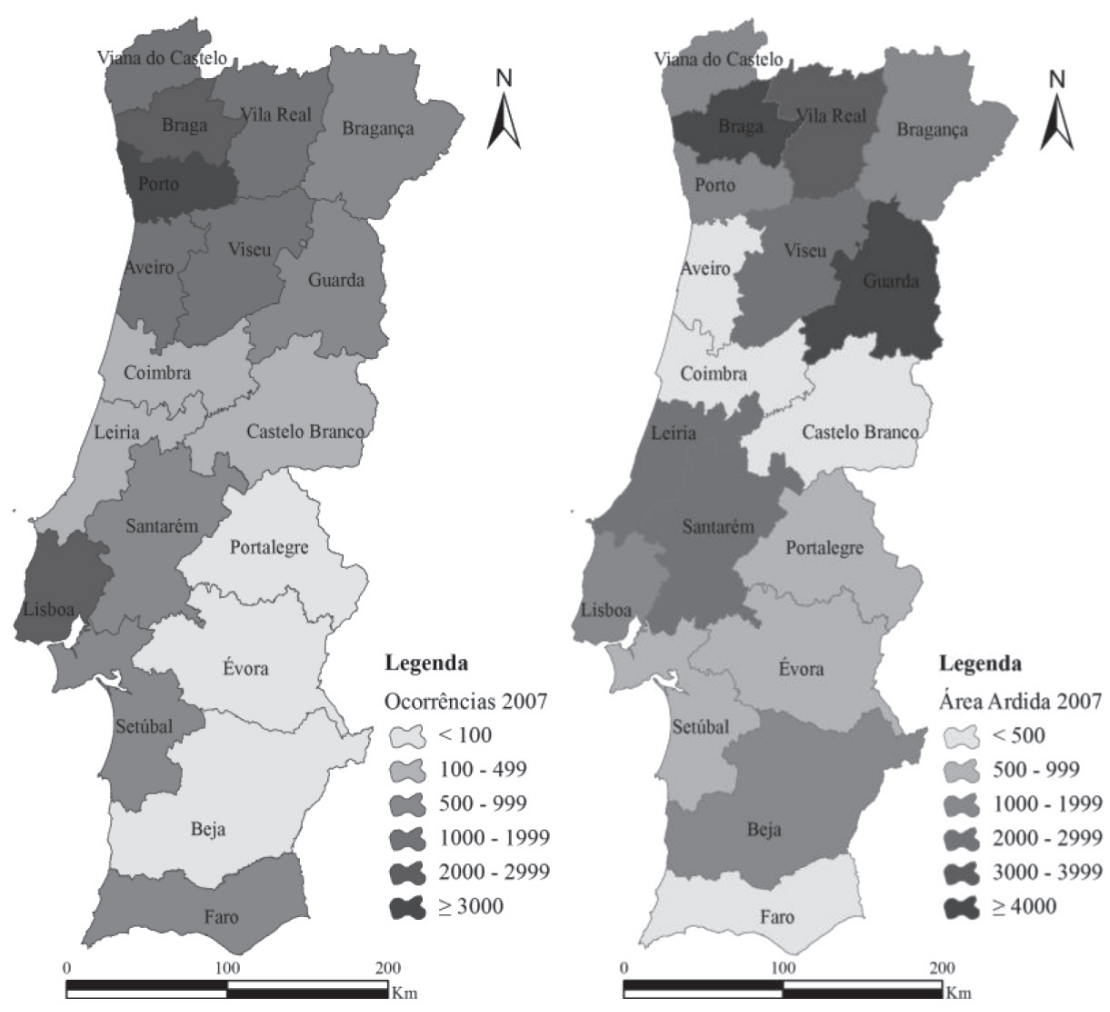

Figura 24

Distribuição, por distrito, do número total de ocorrências (à esquerda) e das áreas ardidas em hectares (à direita), em Portugal continental, no ano de 2007

Fonte dos dados: Autoridade Florestal Nacional. 
tubro e novembro, vieram "estragar" as estatísticas de um ano que poderia ter sido ainda mais excecional, em termos de incêndios florestais.

\section{Estudo de caso: o município de Coimbra}

Pelas características mediterrâneas do seu clima, a cidade de Coimbra dispõe, por vezes durante períodos de tempo relativamente extensos, de condições favoráveis à ocorrência de incêndios florestais (REBELO, 1980), o que, associado ao crescente aumento de espaços incultos à volta da cidade e, por conseguinte, de maior área de mato e de povoamentos florestais, leva a uma certa probabilidade da ocorrência de incêndios florestais nas imediações de Coimbra. Por outro lado, o movimentado relevo que rodeia a cidade, exceto a poente, cria condições para o fácil desenvolvimento dos incêndios, pelo que não será de admirar que, no presente, o risco de incêndio florestal seja o mais temido pela população conimbricense, especialmente quando este risco se transforma em perigo e, mais ainda, quando passa a crise (LouRenço, 1996).

Em termos de evolução anual da área ardida no concelho de Coimbra no período compreendido entre 1980-2010, distinguiram-se claramente os anos de 1995 e de 2005 , respetivamente com cerca de 3000 hectares e perto de 4500 hectares queimados. Por sua vez, o ano de 1997 correspondeu ao de menor área ardida, com apenas 5,3 hectares.

Em termos da evolução anual do número de ocorrências, os dois anos que se revelaram mais pro- blemáticos foram os de 1985 e 1995, tendo-se aproximado das 200 ocorrências (Figura 25), enquanto o ano de 1980 foi aquele que registou o menor número de incêndios, apenas 5 .

Nesta série de 30 anos, houve uma grande variabilidade anual do número de ocorrências, com 8 desses anos a registarem menos de 50 ignições por ano, ao passo que a maioria deles, 17 , o que corresponde a mais de metade dos anos, registaram valores compreendidos entre 50 e 100 ocorrências. Dois anos, de 1987 e 2005, situaram-se entre 100 e 150 ignições, um valor já bastante elevado e, com um valor excecional, encontramse três anos, 1985, 1986 e 1995, com um número anual superior a 150 incêndios.

Curiosamente, a distribuição das ocorrências nestes cinco anos com valores mais elevados, mostram, por um lado, uma certa tendência para a concentração em três anos consecutivos, 1985, 1986 e 1987, e, por outra parte, uma certa tendência para uma dispersão cíclica, com um período de retorno de 10 anos, como sucedeu em 1985, 1995 e 2005. Ora, como estes dois últimos anos foram, também, aqueles que registaram maiores áreas ardidas, provavelmente as condições meteorológicas que thes estiveram associadas foram favoráveis à ignição e desenvolvimento de incêndios florestais.

\subsection{Os anos de 1995 e 2005, como modelo de condições meteorológicas favoráveis à ocorrência e progressão de incêndios florestais}

Tendo em conta que foram os anos de 1995 e de 2005 aqueles que, no concelho de Coimbra, mais se sa-

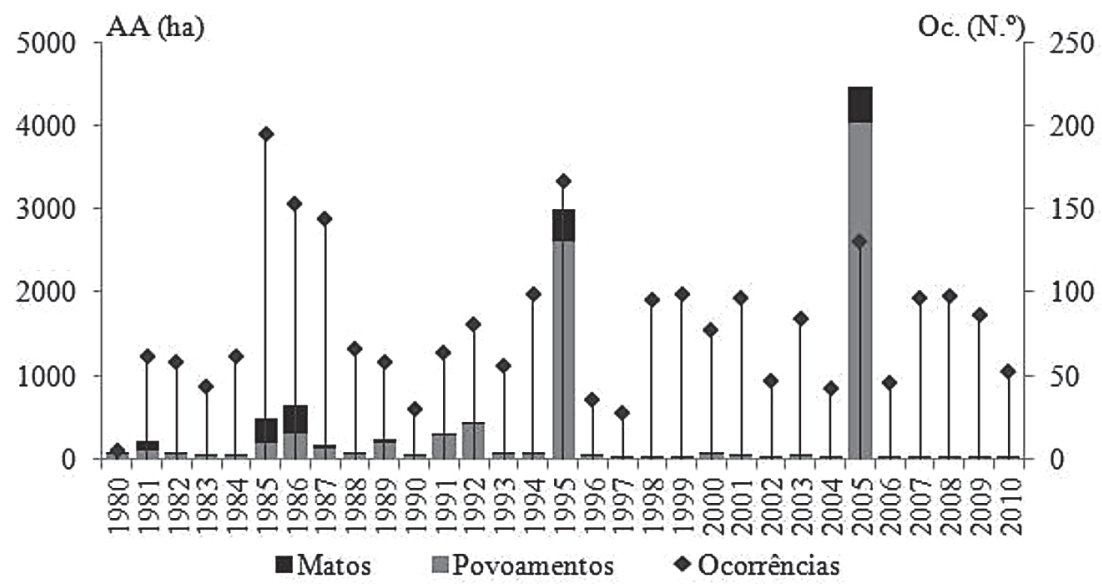

Figura 25

Área Ardida total em hectares (Matos e Povoamentos) e número de ocorrências entre 1980-2010, no concelho de Coimbra.

Fonte dos dados: Autoridade Florestal Nacional. 
lientaram em termos de área ardida e em número de ocorrências, justifica-se uma análise às condições meteorológicas que se fizeram sentir nesses anos com o objetivo de estabelecer eventuais relações.

Assim, com recurso aos dados meteorológicos do Instituto Geofísico da Universidade de Coimbra, procedeu-se à análise dos valores das temperaturas médias mensais, da média mensal das temperaturas máximas diárias e da média mensal das temperaturas mínimas diárias, utilizando sempre como valor de referência a normal climatológica de 1981-2010.

Relativamente aos valores das temperaturas médias mensais para o ano de 1995, verificou-se a predominância de valores acima dos normais (1981-2010), com exceção do mês de setembro. Por apresentarem valores muito superiores, destacaram-se os meses de março $\left(+3,9^{\circ} \mathrm{C}\right)$ e de agosto $\left(+1,7^{\circ} \mathrm{C}\right)$. $\mathrm{O}$ ano de 2005 também não foi muito diferente, visto que, com exceção dos meses do final do outono, inverno e início da primavera, os restantes apresentaram valores superiores aos da normal (Figura 26).

Relativamente à média mensal das temperaturas máximas diárias do ar, o ano de 1995 caracterizou-se por apresentar valores de temperatura superiores aos da normal 1981-2010, excetuando o mês de setembro que registou $1,9^{\circ} \mathrm{C}$. Os meses de abril e de outubro foram aqueles que maiores temperaturas registaram, respetivamente com $+3,7$ e $+3,4^{\circ} \mathrm{C}$ do que o normal. Quanto ao ano de 2005 , excetuando os meses de fevereiro e de novembro, o ano caracterizou-se por apresentar valores médios de temperatura máxima do ar mais elevados do que os valores de referência, em especial nos meses de junho e agosto, com $+3,4 \mathrm{e}+2,6^{\circ} \mathrm{C}$ respetivamente (Figura 27).

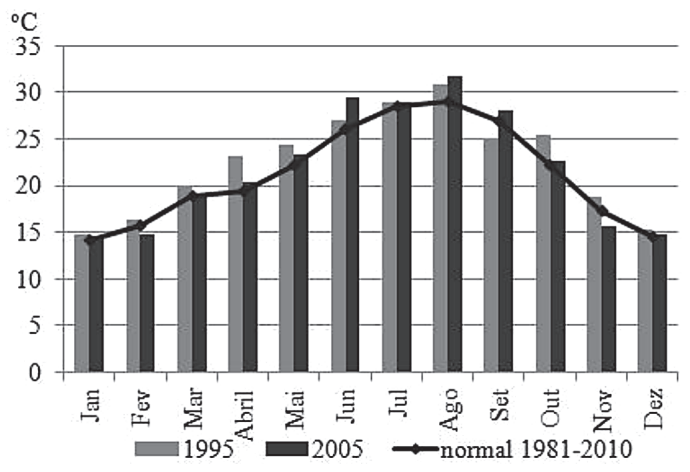

Figura 27

Distribuição do valor médio mensal da temperatura máxima nos anos 1995 e 2005, e relação com os valores da normal climatológica 1981-2010, para o concelho de Coimbra.

Fonte dos dados: Instituto Geofísico da Universidade de Coimbra.

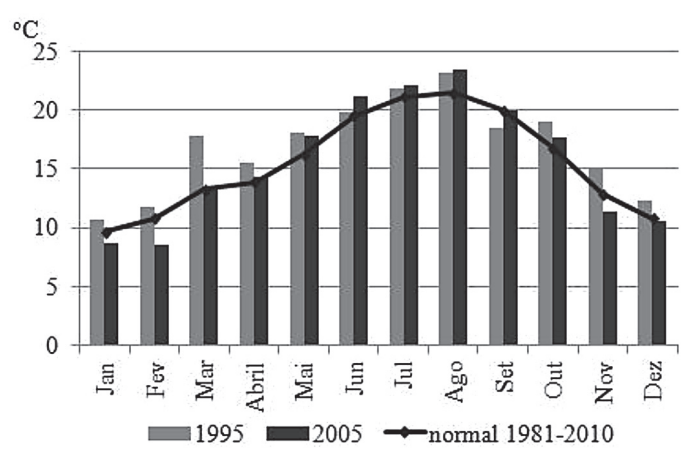

Figura26

Temperatura média mensal em 1995 e 2005 no concelho de Coimbra e sua relação com os valores da normal climatológica 1981-2010.

Fonte dos dados: Instituto Geofísico da Universidade de Coimbra.

Em termos dos valores da média mensal das temperaturas mínimas do ar para o ano de 1995 verificou-se que também foram mais elevados, exceto no mês de setembro, que registou valores inferiores aos da normal. Durante este ano a persistência de temperaturas mais elevadas não se centrou apenas durante os meses de verão, uma vez que também os meses de inverno foram mais quentes do que o normal (Figura 28). Por seu lado, o ano de 2005 registou, de março até outubro, valores médios mensais de temperaturas mínimas mais elevados do que os normais (1981-2010), sendo que os maiores desvios dos valores da temperatura mínima ocorreram durante os meses de verão, em especial nos meses de junho e agosto, que apresentaram +1,6 e +1,1 ${ }^{\circ} \mathrm{C}$ respetivamente. Os meses de final do outono e inverno foram mais frescos, apresentando valores inferiores aos normais (Figura 28).

Para além das temperaturas, também os valores da precipitação registada ao longo do ano são uma

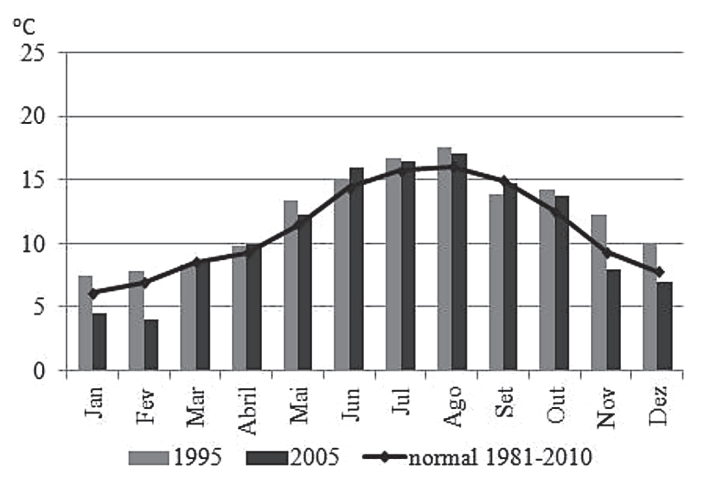

Figura 28

Distribuição do valor médio mensal da temperatura mínima nos anos 1995 e 2005, e relação com os valores da normal climatológica 1981-2010 para o concelho de Coimbra.

Fonte dos dados: Instituto Geofísico da Universidade de Coimbra. 
variável importante para se estabelecer uma relação com os incêndios florestais, pois, como vimos, a pluviosidade vai interferir na humidade dos combustíveis e, consequentemente, na maior ou menor probabilidade de ignição dos mesmos.

Assim, em termos dos totais de precipitação, o ano de 1995 caracterizou-se por apresentar um inverno bastante pluvioso, registando quedas pluviométricas superiores aos valores normais, no período de 19812010, com destaque para o mês de dezembro, com mais $142,11 \mathrm{~mm}$. Os meses de setembro e de novembro foram também pluviosos, com valores próximos dos normais. Nos restantes meses do ano, a precipitação registada foi sempre inferior aos valores normais, em especial durante os meses de verão, não tendo existido qualquer precipitação nos meses de julho e agosto. Por sua vez, o ano de 2005 caracterizou-se por ser um ano seco, pois, em todos os meses, o valor de precipitação foi sempre inferior à normal (1981-2010), mormente nos meses de janeiro, fevereiro, março, julho e agosto, que não apresentaram qualquer registo de precipitação (Figura 29).

Esta secura, que caracterizou os anos de 1995 e, especialmente, o de 2005, associada a elevados valores de temperatura do ar, facilitou tanto a ignição de grande número de incêndios florestais, como, sobretudo, a propagação das chamas e, por conseguinte, a vastidão das áreas ardidas.

Em termos de incêndios florestais, o ano de 1995 registou, logo nos meses de março e abril, várias ocorrências, apesar da área ardida não ter sido extensa. Depois, no final do mês de maio deu-se início a uma nova

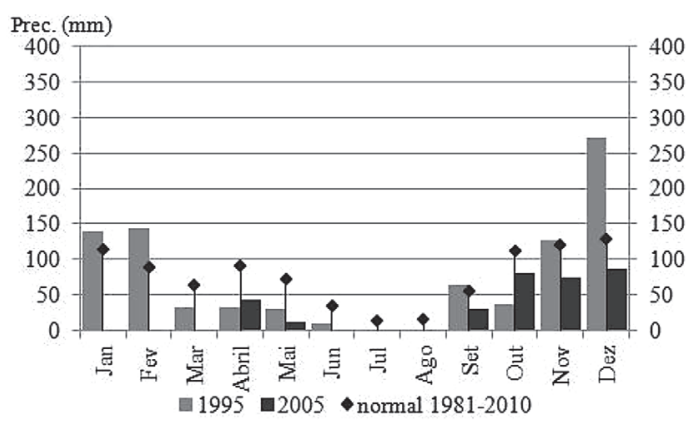

Figura 29

Precipitação mensal em 1995 e 2005 e relação com o valor normal no período de 1981-2010, em Coimbra.

Fonte dos dados: Instituto Geofísico da Universidade de Coimbra.

série de ocorrências que só terminou em outubro, com os meses de julho e agosto a registarem o maior número de ocorrências neste ano. Em termos de área ardida, houve uma grande concentração em apenas dois dias, nomeadamente a 23 de julho e a 13 de agosto, respetivamente com 1889,01 e 1020 hectares (Figura 30).

Contudo, para melhor se perceber a relação existente entre condições meteorológicas e incêndios florestais fez-se uma análise diária às variáveis meteorológicas mais significativas, temperatura máxima do ar $\left({ }^{\circ} \mathrm{C}\right)$, humidade relativa mínima $(\%)$ e precipitação $(\mathrm{mm})$, comparativamente como o número diário de ocorrências de incêndios registados em cada um desses anos.

Quando analisamos as variáveis meteorológicas do ano de 1995, verificamos que a partir de meados do mês de março a temperatura máxima diária do ar

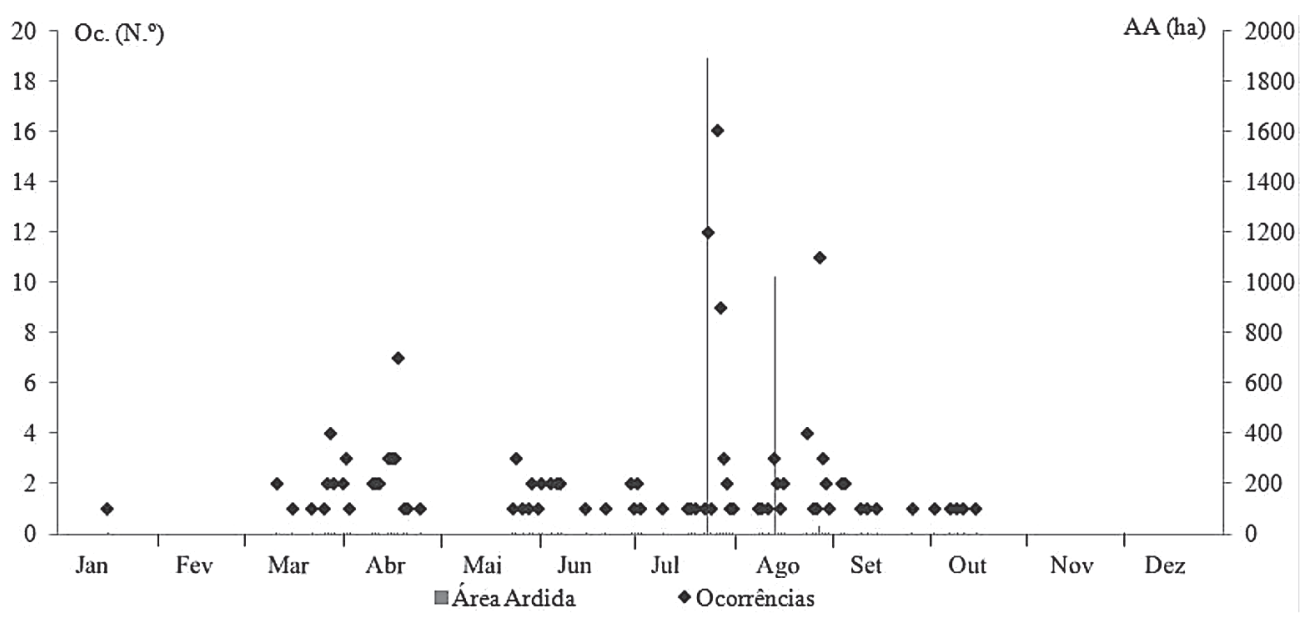

Figura 30

Distribuição dos valores diários do número de incêndios florestais e da área ardida total em hectares, no ano de 1995, para o concelho de Coimbra.

Fonte dos dados: Autoridade Florestal Nacional. 
passou a registar valores mais elevados, o que conjugado com a escassa ou inexistente precipitação e a baixa humidade relativa que, a partir de então, se fizeram sentir, criaram condições favoráveis à ocorrência de incêndios florestais, tanto mais que, a partir do mês de março, a precipitação se apresentou com valores reduzidos e com vários dias sem queda pluviométrica.

No mês de abril verificou-se a continuação de temperaturas elevadas, especialmente entre os dias 6 e 17, bem como valores de humidade relativa bastante reduzidos. De facto, foi nos dias 30 e 31 de Março e 1 , 10,14 e17 de abril que se verificaram o $2^{\circ}, 4^{\circ}$ e $5^{\circ}$, menor valor de humidade relativa mínima (respetivamente $22,25,25,22,24$ e 22 \%). Estas condições, associadas à inexistência de pluviosidade, levaram à ocorrência de vários incêndios florestais. Nos últimos dias do mês, com a queda de pluviosidade, acompanhada de brusca diminuição da temperatura do ar e o consequente aumento dos valores de humidade relativa, para cerca de $80 \%$, verificou-se uma substancial redução do número de ocorrências, bem como das áreas ardidas.

Depois, durante os meses de verão, precipitação e humidade relativa do ar voltaram a ser reduzidas e a temperatura elevada, como é habitual, em especial durante o mês de agosto, o que contribui para nova vaga de incêndios (Figura 30). A partir do dia 5 de setembro verificou-se queda pluviométrica durante vários dias consecutivos, o que acabou por ser prejudicial à ocorrência de incêndios florestais, situação que se manteve durante os meses de novembro e de dezembro, devido a um aumento significativo da precipitação (Figura 31).
Para estabelecer a relação existente entre condições meteorológicas e incêndios florestais aplicou-se o índice de risco meteorológico proposto por L. LOURENço (2004) o qual refere que para valores iguais ou superiores à unidade, estamos perante situações de risco elevado de ignição de incêndio florestal, o qual será tanto maior quanto mais elevado for esse valor. Pelo contrário, para valores inferiores à unidade, o risco considera-se moderado ou reduzido (Quadro I).

Deste modo, aplicando a fórmula ao ano de 1995, verificamos que foram encontrados dois dias com risco máximo, 24 de julho e 26 de agosto, respetivamente com valores de temperatura máxima de $40,3^{\circ} \mathrm{C}$ e $37,2^{\circ} \mathrm{C}$ e humidades relativas mínimas de 19 e $18 \%$. Na classe de risco muito elevado situaram-se os dias 25,28 e 29 de agosto (Figura 32).

No ano de 2005, a maior concentração de incêndios registou-se nos meses de julho e agosto, respetivamente 36 e 39 ocorrências. A área ardida foi quase exclusiva do mês de agosto, tendo ardido mais de 4400 hectares no concelho, seguindo-se o mês de julho, com

Quadro I

Definição das classes de risco, segundo o modelo proposto por Luciano Lourenço

\begin{tabular}{|c|l|l|l|}
\hline Classe de risco & Grau de risco & Intervalo de classe & Classe de risco \\
\hline 1 & reduzido & $0,00-0,49$ & verde \\
\hline 2 & moderado & $0,50-0,99$ & amarelo \\
\hline 3 & elevado & $1,00-1,49$ & laranja \\
\hline 4 & muito elevado & $1,50-1,99$ & vermelho \\
\hline 5 & máximo & $\geq 2,00$ & Vermelho escuro \\
\hline
\end{tabular}

Fonte: LOUREnço, 2004

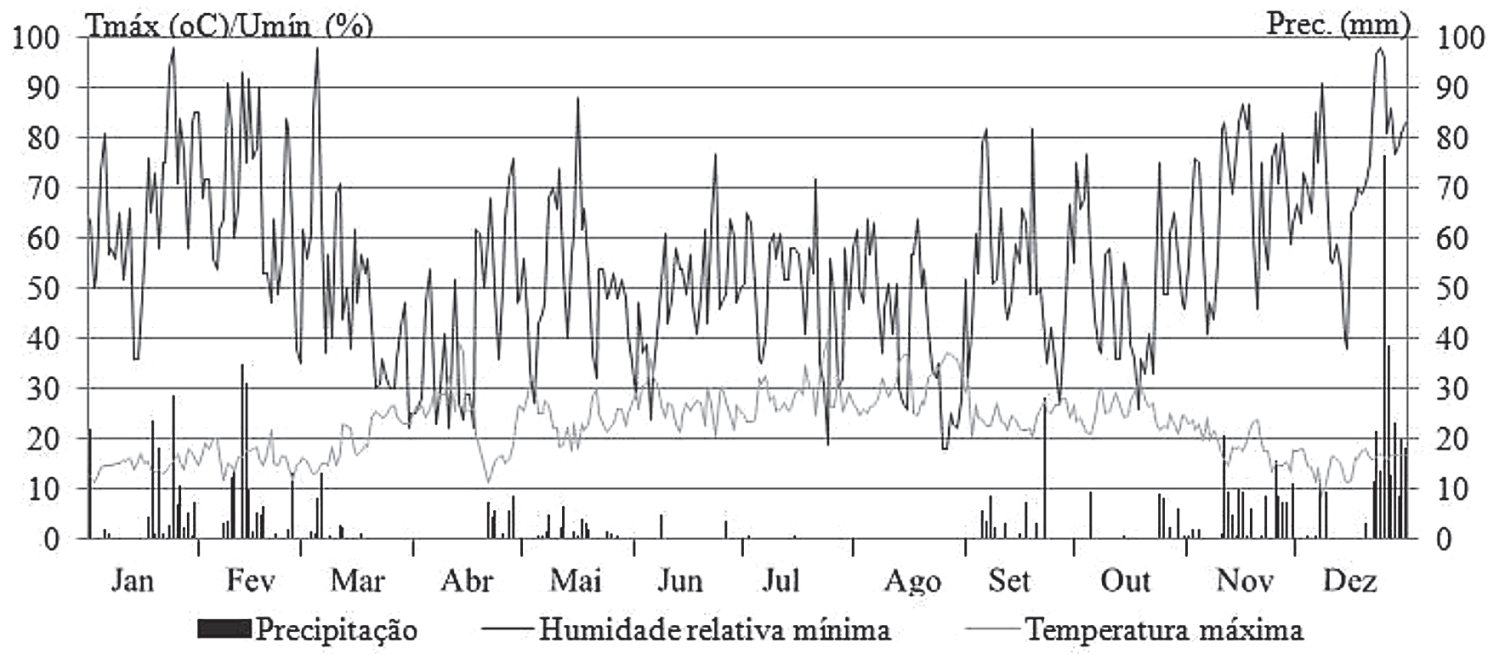

Figura 31

Distribuição dos valores diários da temperatura máxima do $\operatorname{ar}\left({ }^{\circ} \mathrm{C}\right)$, da humidade relativa mínima $(\%)$ e da precipitação (mm) registados ao longo do ano de 1995, para o concelho de Coimbra.

Fonte dos dados: Instituto Geofísico da Universidade de Coimbra. 
uma área bastante inferior, correspondente a menos de 15 hectares (Figura 33).

Averiguando as condições meteorológicas que se fizeram sentir nesse ano de 2005, verificamos que nos primeiros meses do ano, de janeiro a março, a precipitação foi escassa, pelo que estes meses foram muito secos, o que levou a que a humidade relativa também se tivesse apresentado bastante reduzida, em especial nos meses de fevereiro e março. No mês de abril registou-se alguma precipitação, embora muito reduzida quando comparada com a normal. A partir do final do mês de abril verificou-se um aumento progressivo da temperatura do ar, que se manteve elevada durante os meses de verão, ultrapassando $30^{\circ} \mathrm{C}$ no mês de agosto. Por sua vez, a humidade relativa mínima atingiu valores bastante reduzidos neste período (Figura 34), o que determinou vários dias com risco máximo de incêndio florestal (Figura 35).

Em setembro observou-se alguma queda pluviométrica, mais significativa no dia 6. Contudo, esta situação não se prolongou e, logo a partir do dia 12 , houve novo aumento da temperatura e, consequentemente, redução da humidade relativa, situação que se estendeu até meados do mês de outubro, data a partir da qual a temperatura foi sofrendo uma redução progressiva e houve um aumento dos quantitativos pluviométricos.

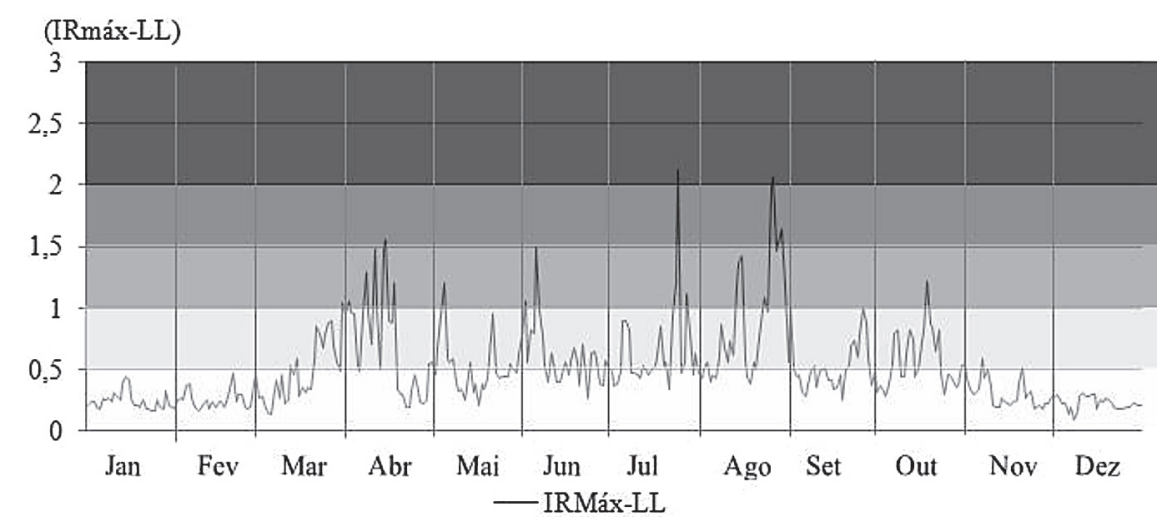

Figura 32

Distribuição diária do Índice de Risco Máximo de incêndio florestal, no ano de 1995, em Coimbra.

Fonte dos dados: Instituto Geofísico da Universidade de Coimbra.

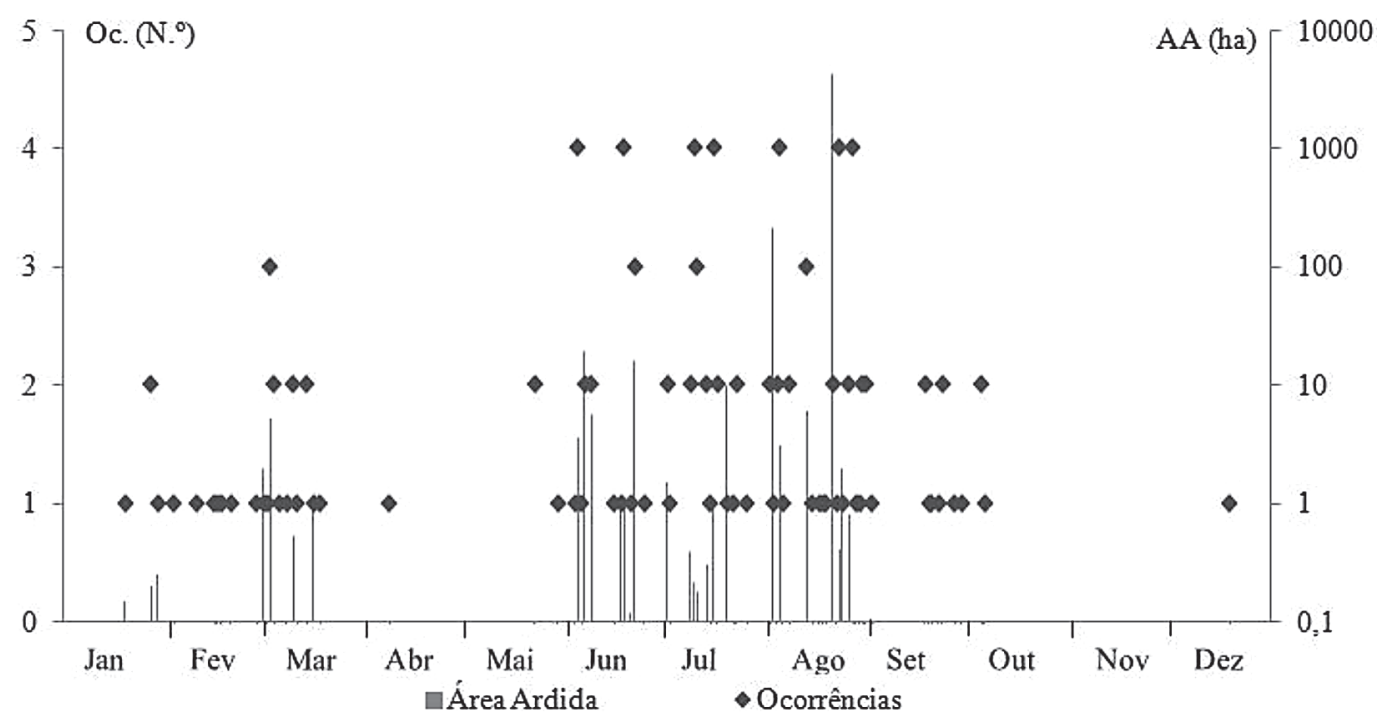

Figura 33

Distribuição diária do número de incêndios florestais e da área ardida total em hectares, no ano de 2005, no concelho de Coimbra.

Fonte dos dados: Autoridade Florestal Nacional. 
Deste modo, os meses de junho, julho, agosto e outubro apresentaram vários dias com índice de risco máximo, especialmente em agosto, e de risco muito elevado. No dia 4 de agosto foi atingido o valor mais alto do índice com um valor superior a 5 (Figura 35).

Como seria de esperar, os dias em que houve maior área ardida, ou seja, 7 e 22 de julho, respetivamente com 19,48 e 16,05 hectares queimados, e os dias 3 e 21 de agosto, com 211,42 e 4178 hectares devastados pelas chamas, apresentavam índice de risco máximo. Nesses dias os valores de humidade relativa foram inferiores a $20 \%$, sendo mesmo inferiores a $13 \%$ nos dias de agosto, e os valores de temperatura máxima situarem-se acima de $30^{\circ} \mathrm{C}$, mais precisamente entre 32 e $40^{\circ} \mathrm{C}$.

3.2. Os anos de 1980 e 1997, como casos de condições meteorológicas adversas a ao desenvolvimento de incêndios florestais

O ano de 1980 foi aquele que, no período de tempo considerado, apresentou o menor número de ocorrências, enquanto o de 1997 teve a menor área ar-

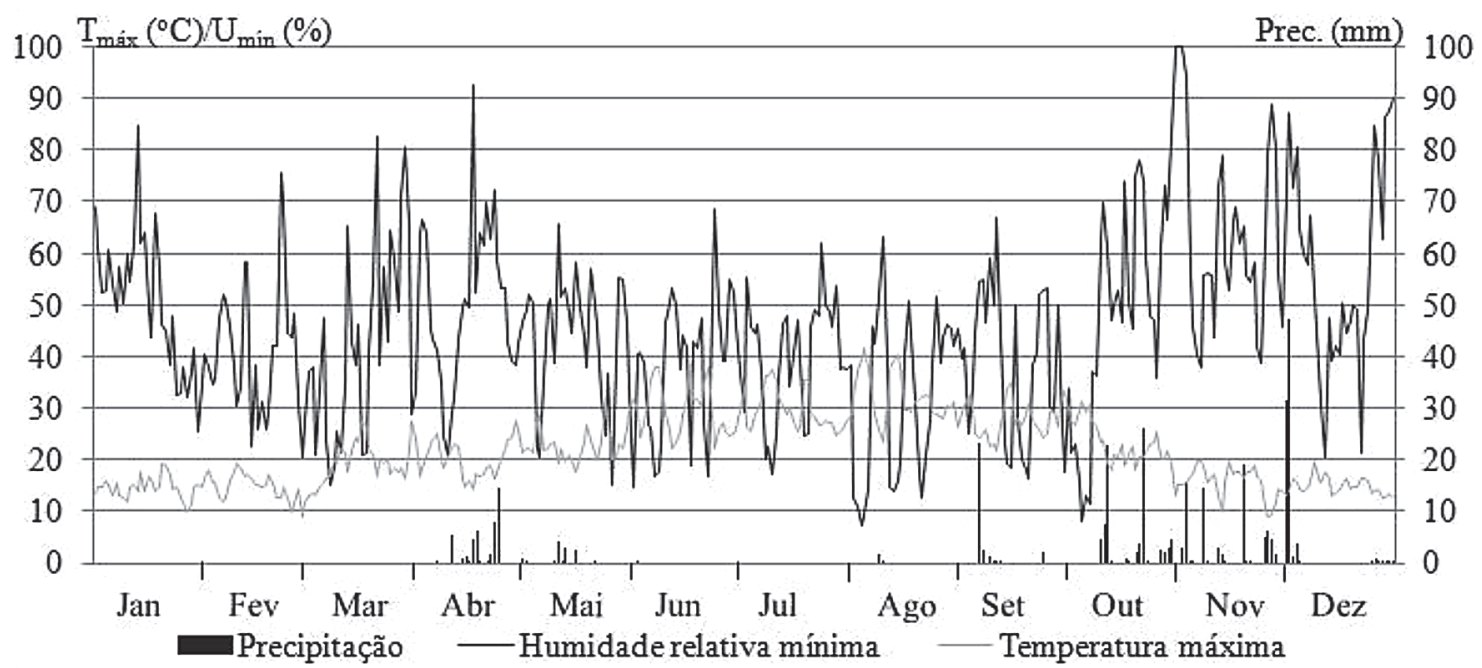

Figura 34

Distribuição dos valores diários da temperatura máxima do $\operatorname{ar}\left({ }^{\circ} \mathrm{C}\right)$, da humidade relativa mínima $(\%)$ e da precipitação (mm) registados ao longo do ano de 2005, em Coimbra.

Fonte dos dados: Instituto Geofísico da Universidade de Coimbra.

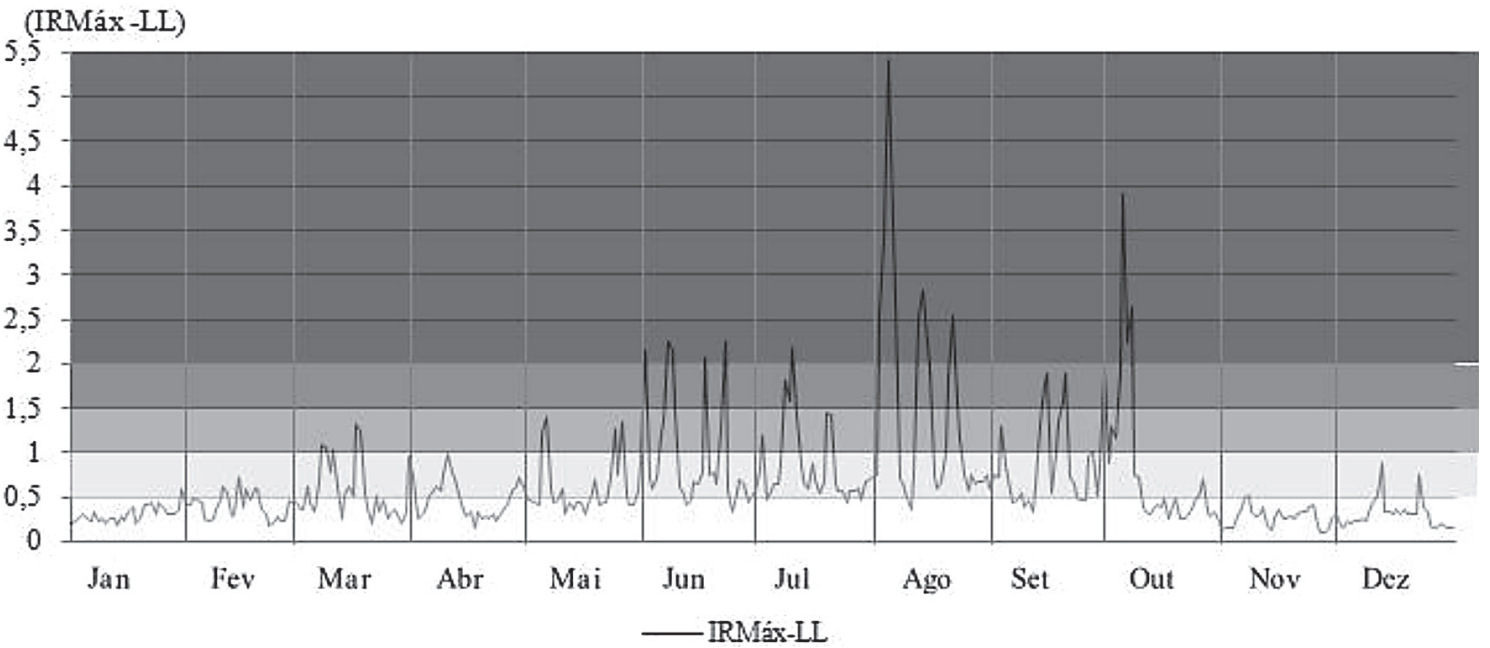

Figura 35

Distribuição diária do Índice de Risco Máximo, no ano de 2005, em Coimbra.

Fonte dos dados: Instituto Geofísico da Universidade de Coimbra. 
dida no concelho de Coimbra, razão porque merecem ser analisados, a fim de podermos comprovar, ou não, a importância das condições meteorológicas adversas na justificação desses valores de incêndios florestais.

Em termos de temperatura média mensal do ar, quase todos os meses do ano de 1980 apresentaram valores inferiores aos normais, uma vez que, apenas nos meses de janeiro e de abril foram superiores. Os meses de junho e julho, com particular significado no que aos incêndios florestais diz respeito, bem como o mês de dezembro, foram os que maior diferença apresentaram em relação à normal, respetivamente $1,8,1,7^{\circ} \mathrm{C}$ e 2,2 , (Figura 36).

No ano de 1997, é de salientar um desvio da temperatura média no mês de fevereiro, com $+1,5^{\circ} \mathrm{C}$ em relação à normal, tendência que se manteve, até com

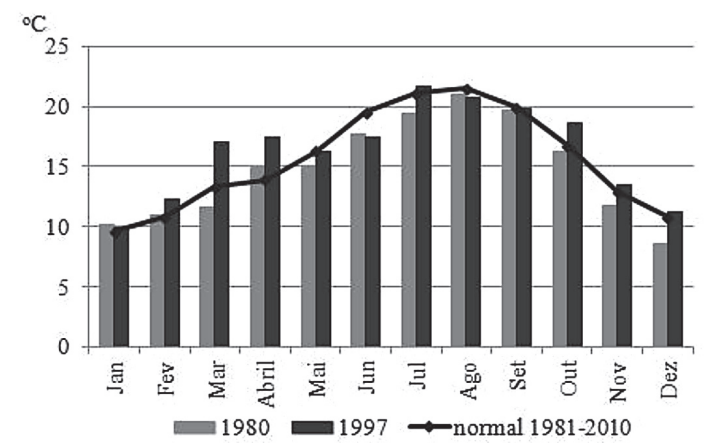

Figura 36

Temperatura média mensal do ar em Coimbra, nos anos 1980 e 1997, e sua relação com o valor da normal climatológica 1981-2010.

Fonte dos dados: Instituto Geofísico da Universidade de Coimbra. maior significado, nos meses de março e abril uma vez que apresentaram desvios de $+3,7 \mathrm{e}+3,5^{\circ} \mathrm{C}$, respetivamente, embora não se tenham registado ocorrências de incêndios. Contudo, nos dois meses seguintes, de maio e junho, foi evidente uma inversão do desvio, com a temperatura média mensal a manter-se sempre inferior ao valor normal. No mês de julho aproximou-se do valor normal e depois, nos meses de agosto e setembro, voltou a ser inferior, tendo regressado a valores superiores aos da normal, a partir de outubro (Figura 36), embora sem consequências em termos de ocorrência de incêndios florestais, atendendo à precipitação registada. Os maiores desvios negativos da temperatura foram registadas nos meses de junho e agosto, respetivamente com 2,1 e $0,8^{\circ} \mathrm{C}$, o que também se repercutiu negativamente na ignição de incêndios florestais.

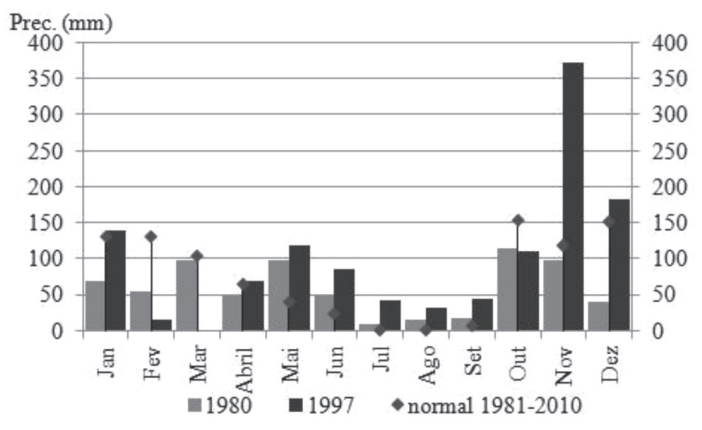

Figura 37

Precipitação mensal em Coimbra, nos anos 1980 e 1997, e sua relação com o valor da normal climatológica de 1981-2010.

Fonte dos dados: Instituto Geofísico da Universidade de Coimbra.

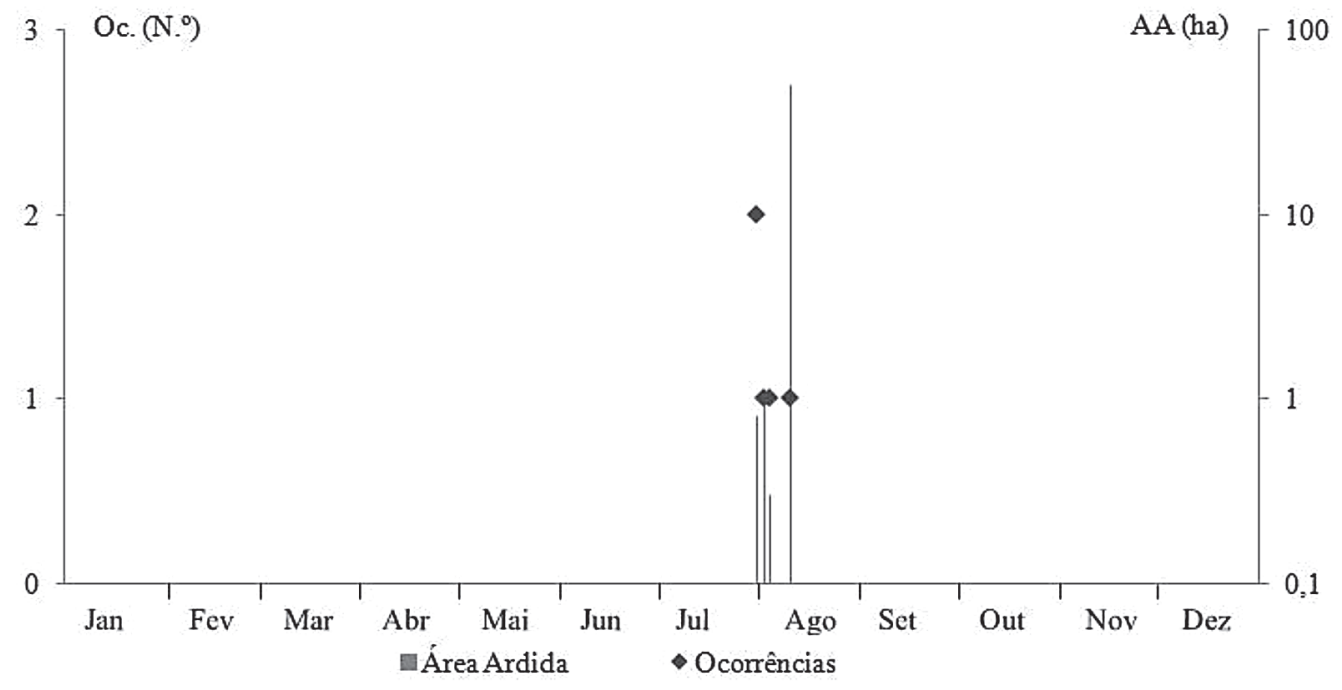

Figura 38

Distribuição diária do número de ocorrências de incêndios florestais e da área ardida (ha), no concelho de Coimbra, durante o ano de 1980. Fonte dos dados: Autoridade Florestal Nacional. 
Em termos pluviométricos, nos dois anos considerados, observou-se precipitação em praticamente todos os meses. São de destacar os valores dos meses de maio a setembro, sempre superiores ao valor normal (Figura 37), fator que certamente muito terá contribuído para que, nestes dois anos, os incêndios florestais tivessem sido mais bem reduzidos, quer em número, quer em área percorrida pelas chamas.

Numa abordagem mais detalhada às condições meteorológicas diárias e às ocorrência dos incêndios florestais que se fizeram sentir nos anos de 1980 e 1997, observa-se que o ano de 1980 foi aquele que, dos dois, registou menor número de ocorrências, apenas 5 , com 2 delas no dia 31 de julho e as restantes nos dias 2, 4 e 10 do mês de agosto. Aárea ardida também foi bastante reduzida, tendo totalizado pouco mais de 50 hectares, praticamente concentrados no incêndio ocorrido no dia 10 (Figura 38).

No que respeita ao comportamento das variáveis meteorológicas em Coimbra, no ano de 1980, verificamos que houve precipitação ao longo de todo o ano, inclusive nos meses de verão. Os valores de humidade relativa mínima foram também elevados, especialmente nos meses de janeiro, fevereiro e março, e mesmo

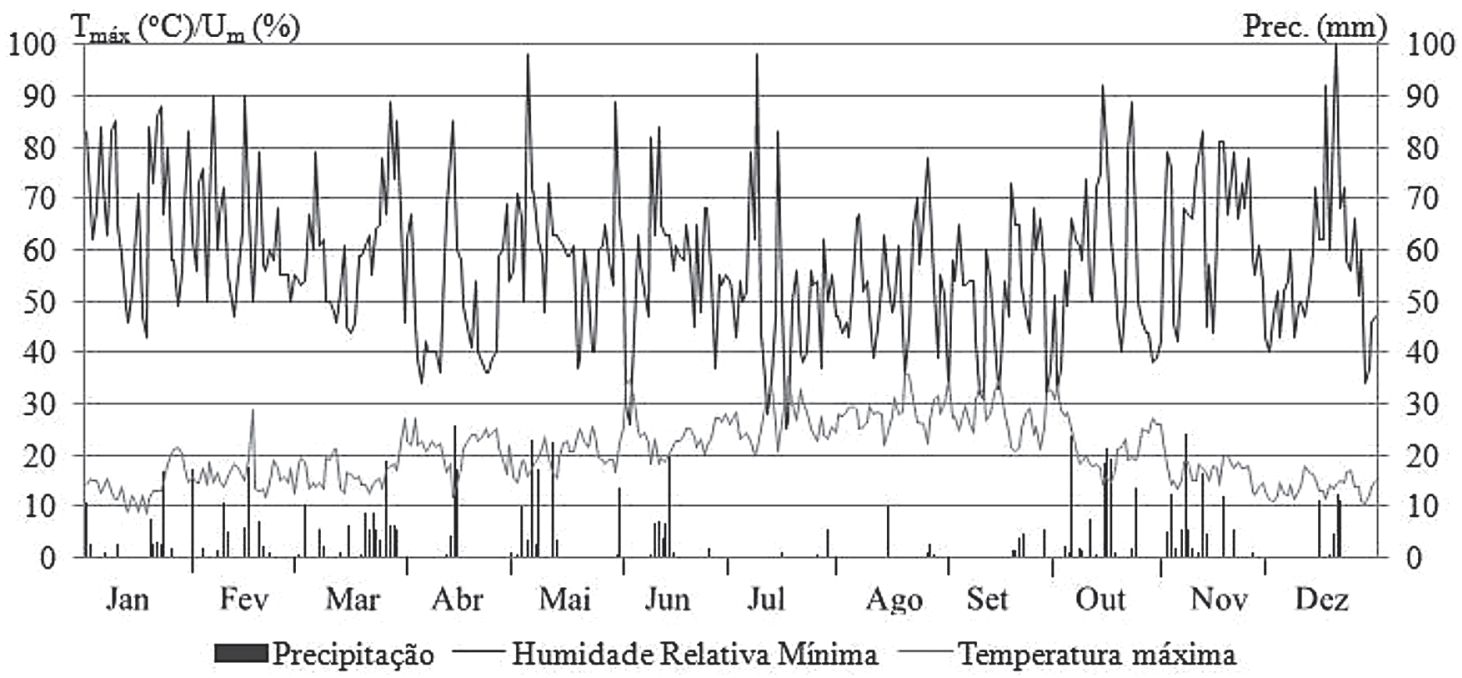

Figura 39

Distribuição diária da temperatura máxima do ar $\left({ }^{\circ} \mathrm{C}\right)$, da humidade relativa mínima (\%) e da precipitação (mm) registadas em Coimbra, ao longo do ano de 1980.

Fonte dos dados: Instituto Geofísico da Universidade de Coimbra.

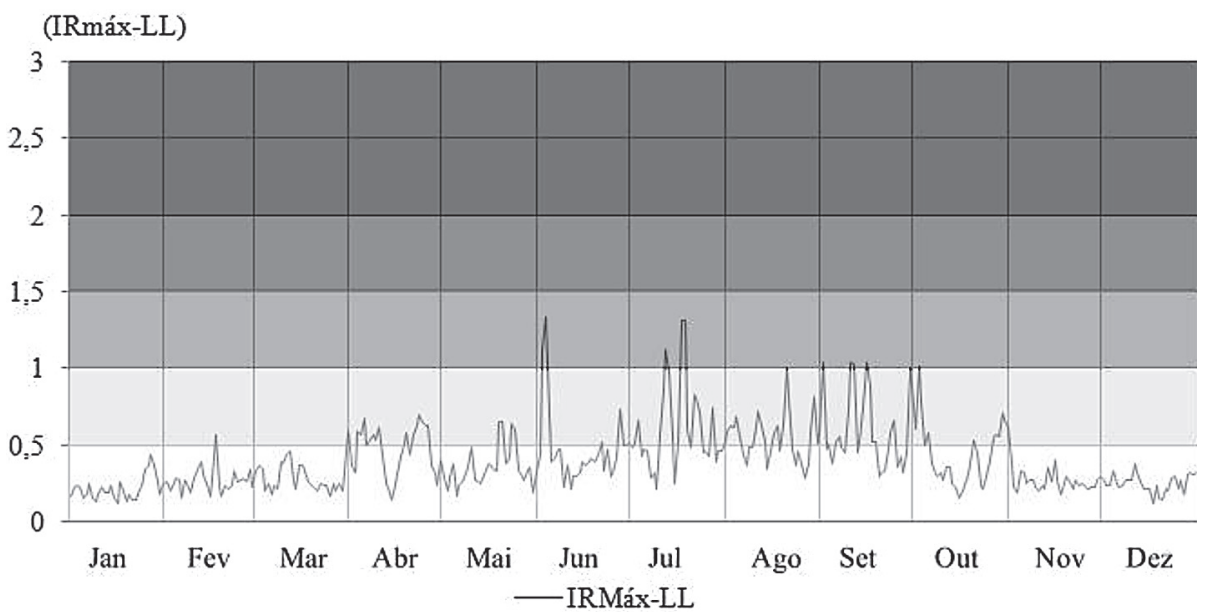

Figura 40

Distribuição diária do Índice de Risco Máximo, no ano de 1980, em Coimbra.

Fonte dos dados: Instituto Geofísico da Universidade de Coimbra. 
durante os meses de verão, apenas os dias 2 e 3 de junho e nos dias 12, 17 e 18 de julho registaram valores de humidade relativa mínima inferior a 30\% (Figura 39), sendo igualmente estes dias que apresentaram índice de risco elevado, juntamente com os dias 1, 10, 11, 15 e 29 do mês de setembro e o dia 2 do mês de outubro (Figura 40). Durante os restantes dias do ano predominaram valores correspondentes a índice reduzido.

Em suma, as características meteorológicas deste ano foram, certamente, um bom contributo para os reduzidos valores de ocorrências e de área ardida, cuja explicação resultará essencialmente desse facto. Averiguando as condições meteorológicas dos dias em que se registaram incêndios florestais verifica-se que, naturalmente, não ocorreu precipitação, mas, em contrapartida, a humidade relativa mínima não se mostrou muito reduzida, o que terá sido determinante para que as áreas ardidas não tivessem sido significativas.

Por sua vez, no ano de 1997, apesar de se ter verificado um maior número de ocorrências do que em 1980, 28 no total, a área ardida foi muito inferior à daquele ano, apenas 5,3 hectares, sendo, por isso, o ano que registou a menor área ardida no período de 1980 2010. Como sucede habitualmente, houve uma maior concentração de ocorrências nos meses de julho, agosto e setembro, respetivamente com 9,8 e 8 , cabendo as restantes 3 ao mês de março (Figura 41). No entanto, como vimos, a área ardida foi insignificante, não só porque os quantitativos pluviométricos desses meses foram superiores aos valores normais, mas também porque as temperaturas apresentaram valores mais reduzidos do que os habituais nestes meses (Figura 42).
0 índice de risco máximo diário de incêndio florestal no ano de 1997, mostra que, em Coimbra, em nenhum dia desse ano foi atingido o risco máximo nem sequer o risco muito elevado, ao contrário do que aconteceu, várias vezes, nos anos de 1995 e de 2005. De facto, durante a maior parte do ano de 1997 o risco de incêndio foi reduzido (Figura 43).

\section{Conclusão}

As vastas áreas ardidas em Portugal Continental, especialmente durante a época de verão devem-se à conjugação de vários fatores, de entre os quais ressaltam as condições meteorológicas.

A persistência de determinadas condições meteorológicas e a sua conjugação com eventos extremos, designadamente, vários dias consecutivos com temperaturas máxima e mínima elevadas, associados a ondas de calor e a períodos de seca, propiciam situações muito favoráveis à ignição e propagação de incêndios florestais.

Condições meteorológicas especiais, como é o caso das trovoadas secas, também podem provocar a ignição, embora seja uma situação pouco frequente, mas que se verificou no ano de 2003. Contudo, para o facto de nesse ano se terem registado elevadas áreas ardidas também contribuiu a localização dessas ignições, provocadas por raios, em locais tradicionalmente com poucas ocorrências e, por conseguinte, com um dispositivo de combate a incêndios florestais dimensionado para outra realidade.

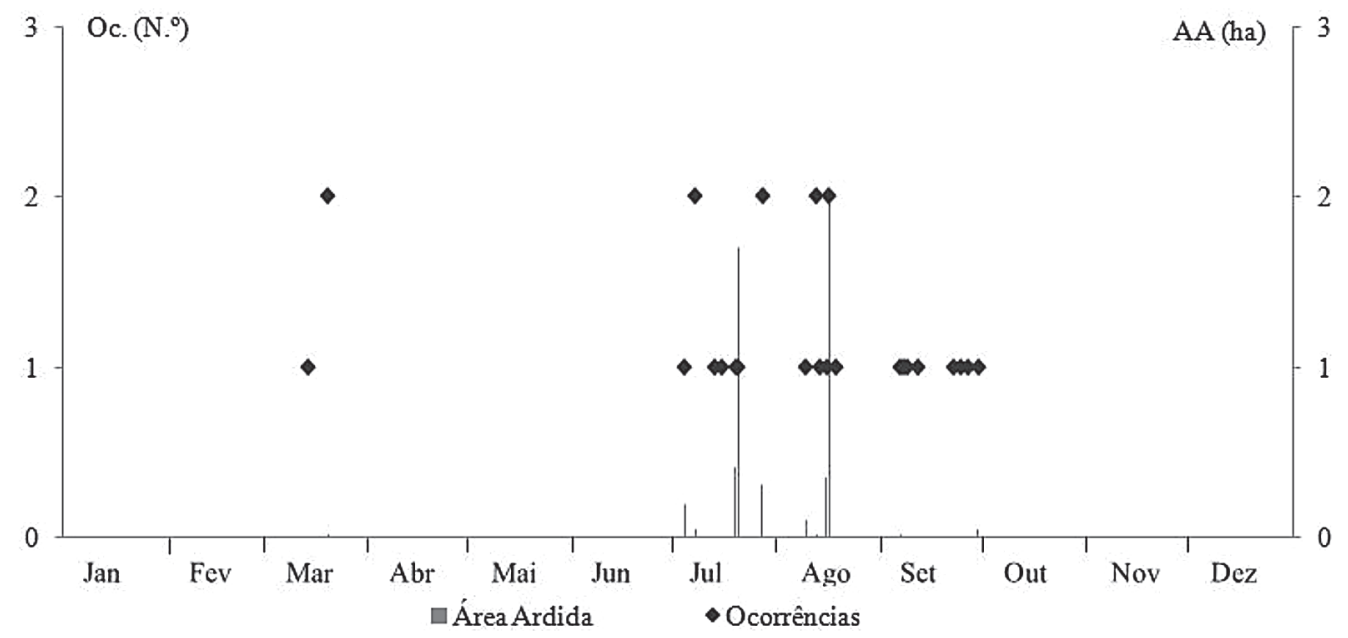

Figura 41

Distribuição diária do número de ocorrências de incêndios florestais e da área ardida (ha) em Coimbra, durante o ano de 1997.

Fonte dos dados: Autoridade Florestal Nacional. 


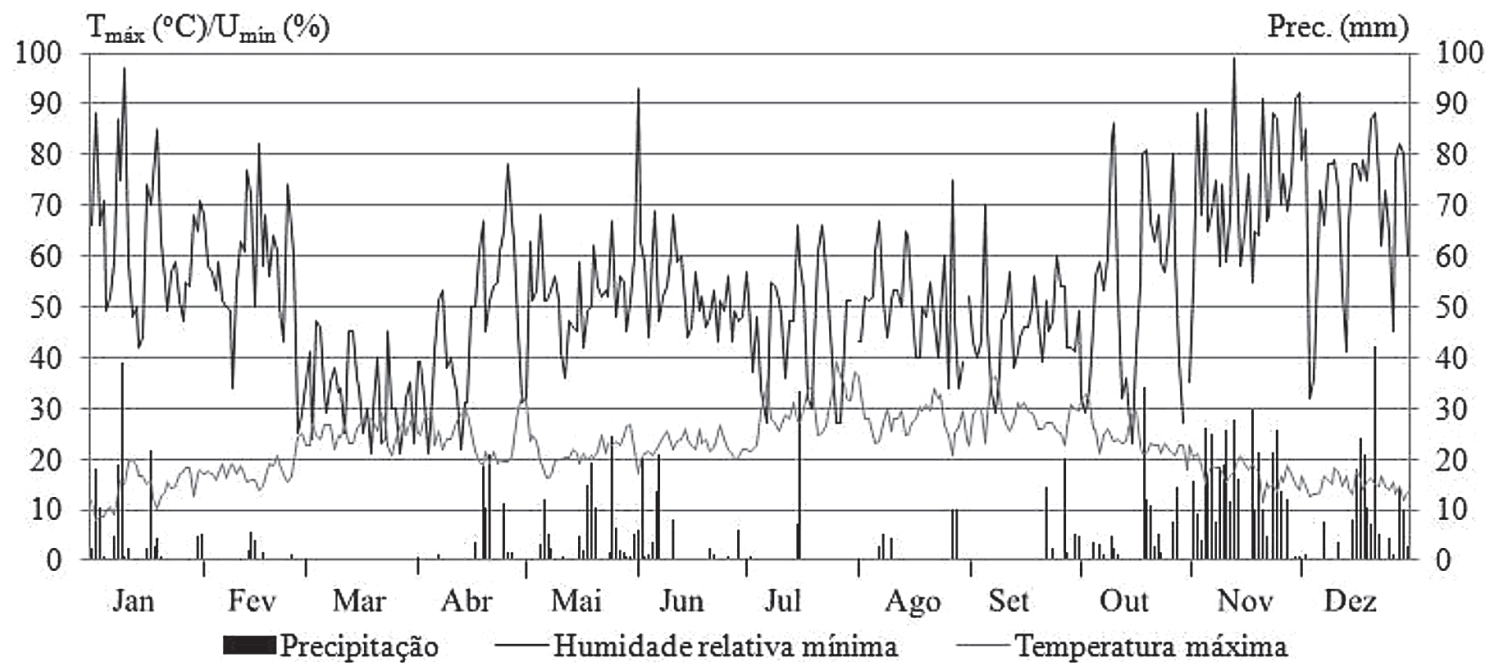

Figura 42

Valores diários da temperatura máxima do ar $\left({ }^{\circ} \mathrm{C}\right)$, da humidade relativa mínima (\%) e da precipitação (mm) em Coimbra, ao longo do ano de 1997.

Fonte dos dados: Instituto Geofísico da Universidade de Coimbra.

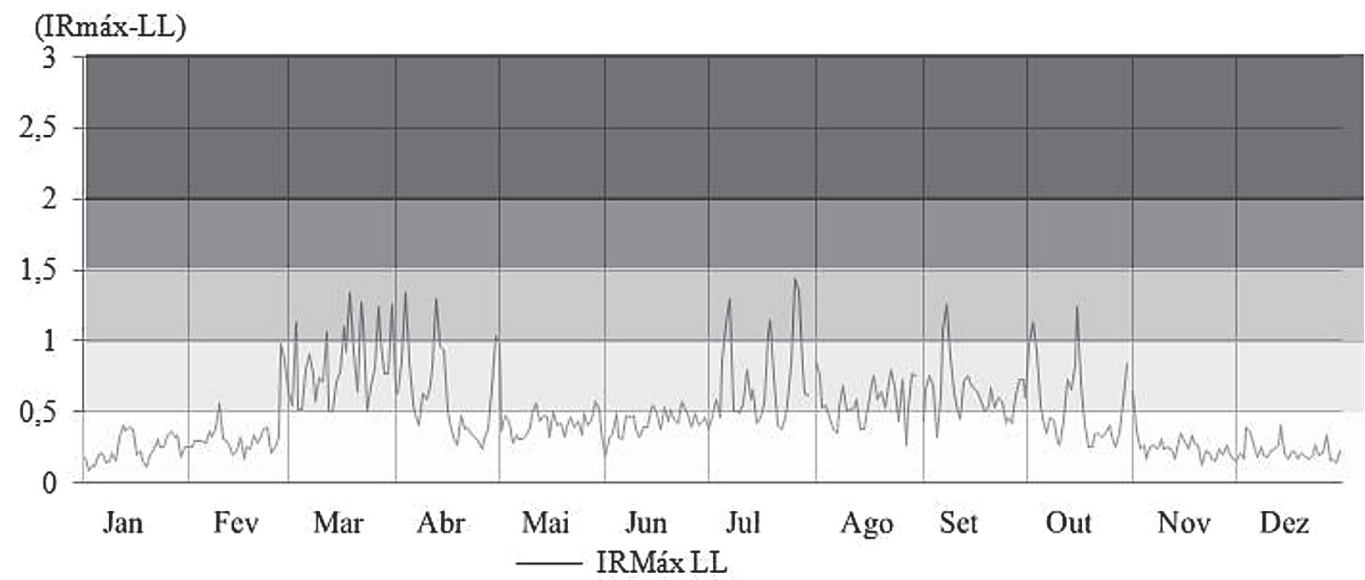

Figura 43

Distribuição diária do Índice de Risco Máximo de Incêndio Florestal, no ano de 1997, em Coimbra.

Fonte dos dados: Instituto Geofísico da Universidade de Coimbra.

Em contrapartida, as condições meteorológicas mais adversas à ocorrência de incêndios florestais, sobretudo na época estival, correspondem a temperaturas máxima e mínima mais baixas do que o normal e, principalmente, quantitativos pluviométricos superiores aos normais que, aumentando o teor de humidade dos combustíveis, prejudicam tanto a ignição dos combustíveis como a propagação dos incêndios.

É óbvio que, além das condições meteorológicas, muitos outros factores são fundamentais para o sucesso das operações de combate aos incêndios florestais. Todavia, sem falsos determinismos, não há qualquer dúvida de que elas condicionam, e muito, as operações de combate, pois, como se procurou demonstar, tanto as podem favorecer como dificultar.

\section{Referências Bibliográficas}

AFN, Autoridade Florestal Nacional (2001-2010) - Relatórios provisórios dos incêndios florestais entre os anos 2001 e 2010: http://www.icnf.pt/portal/florestas/dfci/relatorios; AlmeidA, António C. (2002-2004) - "A floresta na Região Centro e o risco de incêndio: uma reflexão". Cadernos de Geografia, n²1/23, p. 29. Coimbra. 
ANPC, Autoridade Nacional de Protecção Civil (2008) - Directiva operacional nacional $N^{\circ} 1 / 2008$ Defesa da floresta contra incêndios, ANPC, $94 \mathrm{p}$.

APIF, Agência de Prevenção de Incêndios Florestais (2006) Plano nacional defesa da floresta contra incêndios. Um presente para o futuro. APIF, Miranda do Corvo, $86 \mathrm{p}$.

Catarino, Verónica (2003) - "Floresta e incêndios". Revista Técnica e Formativa da Escola Nacional de Bombeiros, $\mathrm{n}^{\circ} 26$, Sintra.

CRAVIDÃo, Fernanda (1990) - "Population and forest fires - some relationships". Proceedings. International Conference on Forest Fires Research, Coimbra, pp. A11-1.

FERREIRINHA, Manuel (1988) - Incêndios florestais, um problema nacional. Lisboa.

ICNF, Instituto da Conservação da Natureza e das Florestas (2012) - Estatística anual do número de ocorrências e área ardida no período de 2001 a 2010 (com base nos dados do SGIF - Sistema de Gestão de Informação sobre Fogos Florestais) http://www.icnf.pt/florestas/dudf/ estatisticas ultima atualização dos dados 2012-06-15).

IM, Instituto de Meteorologia - Boletim climatológico mensal dos anos 2003, 2004, 2005, 2006, 2007, 2008, 2009 e 2010.

IM, Instituto de Meteorologia - Caracterização climática anual dos anos 2004, 2005, 2006, 2007, 2008, 2009, 2010: https://www.meteo.pt/pt/publicacoes/tecnicocientif/nolM/boletins/index.jsp?cmbDep=cli\&cmbTema $=p c l \& i d D e p=c l i \& i d T e m a=p c l \& c u r A n o=-1$.

IGUC, Instituto Geofísico da Universidade de Coimbra "Informação estatística dos dados meteorológicos diários para o período compreendido entre 1971-2010": http://www1.ci.uc.pt/iguc/.

Lourenço, Luciano (1988) - "Tipos de tempo correspondentes aos grandes incêndios florestais ocorridos em 1986 no centro de Portugal”. Finisterra XXIII, 46, Lisboa, pp. 251-270.

LouRENço, Luciano (1995) - "Incêndios florestais passado, presente e futuro. Que futuro?" Recolha Documental, IV Jornadas de Prevenção e Segurança na Floresta de Betão, Associação Nacional de Bombeiros Profissionais, pp. 85-88.

Lourenço, Luciano (1996) - "Coimbra e os riscos naturais, passado e presente". Cadernos de Geografia, N. ${ }^{\circ}$ Especial, pp. 37-43.

Lourenço, Luciano (1991) "Aspectos sócio-económicos dos incêndios florestais em Portugal". Biblos LXVII, Faculdade de Letras da Universidade de Coimbra, Coimbra, pp. 373-385.

LoURENço, Luciano (2004a) - Risco meteorológico de incêndio florestal. Coletâneas Cindínicas II, Núcleo de Investigação Científica de Incêndios Florestais, FLUC, Coimbra, $188 \mathrm{p}$.

Lourenço, Luciano (2004b) - Manifestações de risco dendrocaustológico. Coletâneas Cindínicas IV, Núcleo de Investigação Científica de Incêndios Florestais, FLUC, Coimbra, $174 \mathrm{p}$.

Lourenço, Luciano (2006) - "Incêndios florestais. Algumas reflexões sobre prevenção e mitos do combate", Territorium, Revista da Associação Portuguesa de Riscos, Prevenção e Segurança, Lousã, n 13, p. 59-70: http:// www.nicif.pt/riscos/Documentos/T_PDF/T13artigos/ T13art06.

Lourenço, Luciano (2007) - Riscos ambientais e formação de professores. Coletâneas Cindínicas VII, Núcleo de Investigação Científica de Incêndios Florestais, FLUC, Coimbra.

LOUREnço, Luciano (2008) - "Urban-forest interfaces: a favourable stage for the incidence and development of forest fires in Portugal". Australasian Journal of Disaster and Trauma Studies, http://www.massey.ac.nz/ trauma/ issues/2008-2/lourenco.htm.

Lourenço, Luciano e RaInHA, Manuel (2006) - "As mediáticas 'mãos criminosas dos incendiários' e algumas das 'lições dos fogos florestais de 2005' em álbum fotográfico. Contributo para a desmistificação dos incêndios florestais em Portugal”. Territorium, Revista da Associação Portuguesa de Riscos, Prevenção e Segurança, Lousã, n 13, p. 71-82: http://www.nicif.pt/ riscos/Documentos/T_PDF/T13artigos/T13art07.

MENDES, Carlos (2003) - Incêndios Florestais e Onda de Calor. Análise do período entre 27 de Julho e 15 de Agosto de 2003. Relatório Preliminar. Divisão de Riscos Naturais e Tecnológicos da Direção de Serviços de Prevenção e Proteção, Serviço Nacional de Bombeiros e Proteção Civil, Carnaxide, 27 p.

Nunes, Adélia (2004) - "O 'Baldio do Sabugal': Processo de colonização e evolução do uso do solo". Atas do Congresso da Geografia Portuguesa, 5, Guimarães.

Rebelo, Fernando (1980) - "Condições de Tempo Favoráveis à ocorrência de incêndios florestais. Análise de dados referentes a Julho e Agosto de 1975 na área de Coimbra". Biblos, Coimbra.

Rebelo, Fernando (2003) - Riscos naturais e acção antrópica estudos e reflexões. Imprensa da Universidade, Coimbra ( $2^{\mathrm{a}}$ edição).

Rego, Castro (2003) - "As florestas portuguesas". Ambiente 21 sociedade e desenvolvimento, $\mathrm{n}^{\circ} 11$, ano II, Carnaxide.

SANTO, Fátima Espírito (Coord.) (2006) - Boletim climatológico de 2005. Caracterização climática/ano 2005. Instituto de Meteorologia, Departamento de Acompanhamento do Clima e das Alterações Climáticas, $32 \mathrm{p}$.

\section{Sítiografia}

http://sniamb.apambiente.pt 
http://www.meteo.pt;

http://www.nicif.pt; http://www.afn.min-agricultura.pt.

http://www1.ci.uc.pt/iguc/ 